\title{
Met hart en ziel
}

Citation for published version (APA):

Bar, F. W. H. M. (1999). Met hart en ziel. Universiteit Maastricht. https://doi.org/10.26481/spe.19991001fb

Document status and date:

Published: 01/10/1999

DOI:

$10.26481 / \mathrm{spe} .19991001 \mathrm{fb}$

Document Version:

Publisher's PDF, also known as Version of record

\section{Please check the document version of this publication:}

- A submitted manuscript is the version of the article upon submission and before peer-review. There can be important differences between the submitted version and the official published version of record.

People interested in the research are advised to contact the author for the final version of the publication, or visit the DOI to the publisher's website.

- The final author version and the galley proof are versions of the publication after peer review.

- The final published version features the final layout of the paper including the volume, issue and page numbers.

Link to publication

\footnotetext{
General rights rights.

- You may freely distribute the URL identifying the publication in the public portal. please follow below link for the End User Agreement:

www.umlib.nl/taverne-license

Take down policy

If you believe that this document breaches copyright please contact us at:

repository@maastrichtuniversity.nl

providing details and we will investigate your claim.
}

Copyright and moral rights for the publications made accessible in the public portal are retained by the authors and/or other copyright owners and it is a condition of accessing publications that users recognise and abide by the legal requirements associated with these

- Users may download and print one copy of any publication from the public portal for the purpose of private study or research.

- You may not further distribute the material or use it for any profit-making activity or commercial gain

If the publication is distributed under the terms of Article $25 \mathrm{fa}$ of the Dutch Copyright Act, indicated by the "Taverne" license above, 


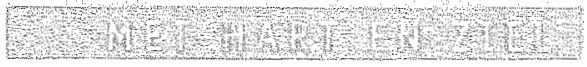

Inaugurale rede, in verkorte vorm uitgesproken bij het aanvaarden van het ambt van Hoogleraar in de Cardiologie, in het bijzonder de Invasieve Cardiologie, aan de Universiteit Maastricht op 1 oktober 1999 door

Dr. F.W.H.M. Bär 


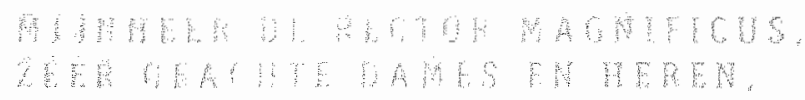

Vandaag zal ik met het uitspreken van deze rede het ambt aanvaarden van Hoogleraar Cardiologie, in het bijzonder de Invasieve Cardiologie.

Het hart speelt in de beleving van de mens een centrale rol. Het hart wordt niet alleen als pomp beschouwd, het is tevens de vertolker van velenlei emoties zowel ten goede als ten kwade. Het betreft bijwoorbeeld liefde (hartendief), verdriet (hartverscheurend), vreugde (hartveroverend), angst (de schrik slaat me om het hart) en verdorvenheid (hartwochtig). Vele godsdiensten hebben hun cultus aan het hart verbonden. In mijn rede zal ik me, met kloppend hart, richten op het hart als orgaan, waarbij de ziel niet zal worden vergeten. Ik wil u schetsen hoe in de afgelopen jaren revolutionaire veranderingen zijn opgetreden in de kennis van diagnostiek en therapie van hart- en vaatziekten. Ik zal hierbij het hartinfarct als. voorbeeld nemen. In mijn rede wil ik starten met een historisch overzicht, om vervolgens de bijdrage van de Maastrichtse cardiologie aan deze ontwikkelingen te bespreken. Tenslotte geef ik u mijn visie over de nabije toekomst. 
Hoewel de symptomen van het hartinfarct al in de oudheid zijn beschreven, was een zekere diagnose pas mogelijk door het registreren van het elektrocardiogram (ECG). De afgelopen 100 jaar hebben Nederlandse wetenschappers hierbij een voortrekkersiol gespeeld. We kumnen onder andere bogen op geleerden zoals Einthoven, die in het begin wan deze eeuw als eerste de elektrische signalen van het hart vastlegde (1). Een tweede Nederlandse pionier die zich in het hart verdiepte was Wenckebach (2). Deze hield zich bezig met de interpretatie van het ECG. Zijn naam zal onverbrekelijk verbonden blijven aan een bepaalde geleidingsstoornis tussen boezem en kamer.

Al ver voor de Tweede Wereldoorlog verkreeg men dankzij secties geleindelijk meer inzicht in de corzaken en de gevolgen van een hartinfarct. Patholoog-anatomen ontdekten dat het hartinfarct berustte op het plotse afsluiten van een kransslagader. In dat vat werden meestal atherosclerotische afwijkingen gezien, in thet Nederlands ook wel aderverkalking genoemd. Toentertijd was de opinie van veel artsen dat het vat geleidelijk dichtslibde hetgeen leidde tot de afsluiting van het vat. Secties maakten echter duidelijk dat de afsluiting werd veroorzaakt door een lokaal stolsel. De laatste jaren heeft men pas kunnen achterhalen hoe dat proces verloopt. In de binnenste wand van het bloedvat, het zogenaamde endotheel ontstaat een scheurtje in de bekleding van een onregelmatige verdikte atherosclerotische plats. Dit scheurtje wordt ook wel een ruptuur of een dissectie genoemd. Het endotheel is een soort huid, gelegen aan de binmenkant van het bloedvat. Door de scheur komt het weefsel onder het endotheel bloot te liggen en treedt in contact met bloed. Het bloed reageert zoals het normaal zal reageren: het zal ter plaatse stollen om verbloeding te voorkomen. Wat elders een zegen is, is in de kransslagader echter een groot gevaar: door het stolsel kan het bloedvat afsluiten, met alle desastreuze gevolgen van dien.

In Maastricht is daarom een muizenmodel ontwikkeld on deze complexe problematiek nauwkeuriger te bestuderen (3). De laatste jaren zijn er aanwijzingen dat ook infecties van de valutwand kunnen meespelen in het proces van atherosclerose. In een ingenieus onderzoek hebben we aangetoond dat onbegrepen uitputting. die veel hartpatienten ervaren voor hun hartinfarct, verband houdt met dergelijke infecties (4). 
Dat een hartinfart tot complicaties kan leiden was voor de jaren ' 40 al rumschoots bekend. Een goed begrip wan de precieze aard van deze complicaties ontbrak echter. Zeer veel infarctpatienten overleden in de acute of subacute fase. Patholoog-anatomen constateerden dat de hartspier achter de afsluiting in de slagader afstierf en in een week of zes geleidelijk vertittekende. In sommige gevallen bleek de geinfarceerde hartspier te scheuren, met de dood tot gevolg. Deze complicatie wordt ook wel tamponade genoemd. Inmiddels weten we dat tamponades relatief zeldzaam zijn en slechts bij circa $1 \%$ van de infarctpatiënten optreden. De belangrijkste oorzaak van overlijden blijkt namelijk niet de tamponade maar een ernstige ritmestoornis te zịn.

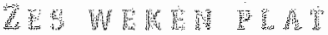

De artsen wilden hun patiënten beschermen tegen het scheuren van het hart. Dit was reden om alte patiënten onverbidd elijk gedurende de zes weken volgende op het infarct volledig te immobiliseren, om zo optimale verlittekening af te wachten. Het infarct werd toen nog miet gedifferentieerd naar plaats en grootte, evenmin keek men naar de resterende functie van het hart. Door de langdurige bedlegerigheid ontwikkelden zich vaak stolsels in benen en bekken. Als patiënten dan uiteindelijk na zes weken werden gemobiliseerd konden deze stolsels losschieten en tot een massale Longembolie leiden, met een plotse dood als gevolg (5-8). De conclusie van de artsen luidde dan: we zijn nog te vroeg geweest met mobilisatie.

De "chair treatment", ontwikkeld en toegepast door Levine en Lown in de jaren '4to, getuigt dan ook van moed (9). Tegen de tijdsgeestin in zetten zij patiënten al drie dagen na het infarct gedurende een à twee uur op een stoel. Geen van de 63 zo behandelde pattënten kreeg emstige complicaties. Levine en Lown publiceerden hun bevindingen in 1952. Door dit onderzoek is de benadering van het hartinfarct zeer geleidelijk gewijzigd, patiënten werden steeds sneller gemobiliseerd. De gevreesde tamponades bleken, zoals eender gezegd, een relatieve zeldzaamheid.

Tekenend voor die tijd was dat ingeslopen gewoontes in de geneeskunde zeer traag veranderden. In Nederland was het tot in de zeventiger jaren bijwoorbeeld nog steeds usance infarctpatiënten vier tot zes weken in bed te stoppen. Met angstig kloppend 
hart - bij zowel patient als arts! - werd daama de mobilisatie gestart. Zoals te verwachten valt, hadden de patiënten dan een ernstige spierverslapping ontwikkeld ten gevolge van de lange bedrust.

Dit wormde de reden om fysieke reconditioneringsprogramma's op te zetten: zo ontstond de "hartrevalidatie". Door de gunstige effecten wan deze programma's durfden artsen hum patiënten vervolgens steeds sneller te mobiliseren $(10,11)$. Dankzij de revalidatie is het momenteel niet ongebruikelijk dat patiènten al een dag na het ontstaan van hun infarct op een stoel gezet worden en binnen een week weer thuis zijn. Door de vroege mobilisatie blijft de fysieke conditie goed, terwijl de psychische klap veel minder hard aankomt. Was een infarctpatient tot in de jaren ' 70 nog een invalide en "cardiac cripple", nu blijven de meeste mensen na een hartinfarct volwaardig lid van de maatschappij. De meeste mensen zijn weer in staat hun normale bezigheden te hervatten $(10,11)$.

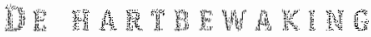

In de zestiger jaren werd duidelijk dat het grootste overlijdensrisico van het acute hartinfarct lag in de ritmestoornis "kamerfibrilleren". Hierbij is de synchronisatie tussen de hartspiercellen in de hartkamers zoek. Alle cellen trakken samen, maar ze doen dit ongecoördineerd, zodat geen bloed meer wordt rondgepompt. Circa éénderde van de acute infarcten overlijdt aan deze ritmestoomis. In die tijd is ook ontdekt dat een elektrische stroomstoot deze letale ritmestoornis in principe weer kan beëindigen. Een andere ontwikkeling was de pacemaker die een andere complicatie van thet hartinfarct kan opvangen, namelijk de extreem langzame hartslag of de hartstilstand.

Deze bevindingen waren reden om hartbewakingsafdetingen, ook wel CCU's genoemd, te installeren. De CCU's werden uitgerust met continue ECG-bewaking, met defibrillatoren en pacemakers. De CCU gaf bovendien het mieuwe specialisme Cardiologie de kans om zich te profileren ten opzichte van de Interne Geneeskunde, waarvan zij zich inmiddels had losgemaakt. Een dergelijke ontwikkeling gaat niet zonder slag of stoot. Het heeft zeker tien jaar geduurd, en vele mensenlevens gekost, eer het normal was infarctpatienten direct op de ccu op te nemen. Hiertoe het volgende voorbeeld:

HARTENZIEL 
Als jong assistent inteme geneeskunde nam ik een belangrijk industrieel van vijftig jäar op voor de internist - niet woor de cardioloog die toen al beschikte over een goed geoutilleerde CCU. De competentiestrijd tussen beide disciplines was in het betreffende ziekenhuis nog niet witgevochten. De patient had een klein acuut onderwandinfarct; zoals gebruikelijk was de klassenafdeling vol. Reden om hem in de dokterskamer te leggen, wel aan de monitor maar zonder permanente observatie. Nadat ik de man had opgenomen werd ik naar elders geroepen. Tien minuten later, bif mijn terugkomst, bleek patiënt te zijn overleden aan kamerfibrilleren. Een defibrillator was niet aanwezig.

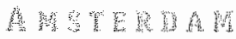

Mijn cardiologische opleiding mocht ik genieten in het Withelminagasthuis (WG) in Amsterdam. Aldaar aangekomen bemerkte ik dat de hartafdeling een grote internationale vermaardheid had. Professor Durrer was hoofd van de afdeling. In een klassiek geworden artikel heeft hij als eerste het normale elektrische activatiepatroon van het menselijk hart beschreven $(12,13)$. De Amsterdamse school heeft ook daarna zeer belangrijk werk verricht op het gebied van de elektrocardiografie en elektrofysiologie, waarbij de namen van Meyler, Schuilenburg en vooral Wellens, mijn latere teermeester, mogen worden genoemd. Bij mijn aankomst in Amsterdam was op het WG-terrein net een nieuw gebouw betrokken, met een riante CCU die onder de bezielende leiding van Lie stond. Dit centrum is waarschijnlijk het eerste ziekenhuis in Nederland geweest dat een Eerste Harthulp had. Het hartinfarct kreeg in het WG ruime wetenschappelijke aandacht, die vooral gericht was op de diagnostiek, behandeling en prognose van de complicaties van het hartinfarct. Zo werd bijvoorbeeld gevonden dat het medicament lidocainne kamerfibrilleren bij het acute infarct kan voorkomem, een bevinding die in later onderzoek overigens niet kon worden bevestigd.

De opleiding was zwar en Spartaans, maar buitengewoon leerzam. 0p werktijden werd toen gelukkig nog niet gelet. Opmerkelijk voor die tijd was dat de patient met respect, als een volwaardig medemens, werd behandeld. 
In 1977 volgde de tocht naar Maastricht. Ten gevolge van het ontbreken van goede afspraken tussen het toenmalige Annadalziekenhuis en medische faculteit duurde het vijf jaar eer de cardialogische afdeling zich eindelijk kon ontplooien. De groei van de afdeling is daarna onstuimig geweest. Het unieke van het academisch ziekenhuis Maastricht is de mix van "academische patienten" die van elders worden verwezen met "normale routinepatiènten" die Maastricht in grote getale bezoeken ondat dit het enige ziekenhuis in de regio is. Maastricht heeft daarom de ideale mogelijkheid om wetenschappelijk onderzoek te doen bij de "gewone" patiënt. Voor cen leek lijkt dit mogelijk een uitgekauwd onderwerp, maar niets is minder waar, zoals mijn verdere betoog zal verhelderen.

Hiervoor is echter wel een volwaardige cardiologische kliniek met dottermagelijkheden en een cardiochirurgische afdeling noodzakelijk. De medische faculteit beeft deze ontwikkelingen helaas jaren tegengehouden, ondat de mering heerste dat zulke voorzieningen voor onderwijs en onderzoek op het hartgebied niet nodig waren. Pas na een intensieve lobby tot op hoog niveau werden deze faciliteiten uiteindelijk, in 1986, binnengehaald. Zelfs nu zijn de problemen van de cardiochirurgische kliniek nog steeds niet geheel opgelost, getuige het al jarenlang ontbreken van een afdelingshoofd.

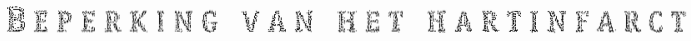

\section{FIERMALTICA}

Zoals eerder aangegeven hadden patholoog-anatomen al vele jaren geleden verkondigd dat de afsluiting van een kransslagader bij het acute hartinfarct meestal. het gevolg is van stolselvorming. De meeste cardiologen volhardden echter in de gedachte dat het bloedvat geleidelijk dichtslibde door vervetting. Toch zijn er in de jaren zestig al enige studies gedalan met stolseloplossende stoffen, ook wel fibrinolytica genoemd. De positieve bevindingen van deze vrij kleinschalige studies zijn echter niet op de juiste wijze geinterpreteend. In 1979 veranderde deze foutieve visie radicaal door de publicatie van Rentrop (14). Hij liet middels hartcatheterisatie zien dat

HARTEHZIEL 
afgesloten waten weer konden worden geopend met de stolseloplossende stof streptokinase. Dankzij dit middel en door andere fibrinolytica kan de grootte van het hartinfarct worden beperkt (15).

Toen de importantie van deze bevindingen tot iedereen doordrong heeft ook onze afdeling research in deze richting opgestart. De eerste grote Nederlandse infarctstudie is die van het Interuniversitair Cardiologisch Instituut Nederland (ICIN genaamd) (16-30). Dit onderzoek startte vrijwel op het moment dat de interne problemen van onze afdeling waren opgelost: het onderzoek viel dus in zeer vruchtbare Maastricitse aarde. De studie onderzocht of de stolseloplossende stof streptokinase het vat weer kon openen als het via een catheter direct werd geinfundeerd in de afgesloten kransslagader. Maar liefst $85 \%$ van de patienten, die aldus werden behandeld hadden na zestig minuten inderdaad een open vat. De klinische uitkomsten wan deze patiënten werden vergeleken met de patiënten die op de klassieke manier werden behandeld (met bedrust). Het aantal patiënten dat overleed daalde dankzij streptokinase spectaculair. Ook allerlei andere complicaties namen dankzij dit "wondermiddel" aanzienlijk af. Later is de aanpak vereenvoudigd, toen bleek dat een infuus in de arm vrijwel even effectief was.

MClNstudig:

phonolyse

$N(10)$

269

Patienter

sterfte
14
$(5,3)$
Controle

N

(1)

264

26
(10) p-waarde
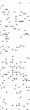

$<0,05$

Nieuw woor die tijd was ook de "cost-benefit" studie van een dergelijke behandeling, tegenwoordig vrijwel een noodzaak bij nieuwe therapieën. Het zal u niet verbazen dat de stolseloplossende stof zéér kosteneffectief was (28). Deze "landmark study" was de eerste in zijn soort, getuige een recent artikel van Kennedy in het cardiologische toptijdschrift Circulation (31). Hij gebruikt bovengenoemde ICINstudie om de voordelen te demonstreren van fibrinolytica. Nat zijn mening is de 
waarde van deze therapie goed vergelijkbaar met die van bypassoperaties en die van dotteren.

Het ICIN-onderzoek illustreerde bovendien de waarde van samenwerking tussen klinieken, iets wat tot die tijd in Nederland eerder uitzondering dan regel was. Voordien zag men elkaar meer als concurrenten. De ICIN-studie had bovendien een belangrijke inwloed op onze afdeling. Gezien de fantastische resultaten veranderde de mentaliteit. Was onderzoek daarvoor naar de mening van menigeen iets dat plaats wond in de achterkamer, en in het algemeen van weinig nut was, nu werd men geconfronteerd met het tegendeel. De afdeling Cardiologie werd geleidelijk "onderzoeksminded", we waren trots op onze wetenschappelijke bijdrage. Dankzij de welwillende medewerking van de directie/rad van bestuur van ons ziekenhuis is de kostbare vierentwintiguurs catheterisatieservice daarna gecontinueerd. inmiddels tot voordeel van vele acute patienten. Om hiervan een kwantitatieve indruk te geven: de twee dienstdoende medewerkers van de catheterisatiekamer werken tezamen met de invasieve cardioloog momenteel gemiddeld 22 uur per persoon per week buiten kantooruren! Dit illustreert ook dat cardiologie fysiek een zwaar beroep is.

Vanwege de Maastrichtse belangstelling voor elektrocardiografie volgde een aantal publicaties, onder andere over de waarde van het ECG bij het bepalen welke patienten het meeste profijt zullen hebben van deze stolseloplossende therapie (16). In een paar wetenschappelijke artikelen lieten we zien dat we dankzij het ECG steeds nauwkeuriger kunnen bepalen wat de exacte plaats van de afsluiting in de kransslagader is $(32,33)$. Verder blijkt het ECG zeer waardevol am aan te tonen of het bloedvat open is na behandeling met het fibrinolyticum (34-40). Deze zogenaamde non-invasieve reperfusiecriteria zijn in de praktijk zeer waardewol gebleken. Het ECG is verder een nuttige parameter om de grootte van het gebied dat door de afslunting wordt bedreigd te bepalen (33). Bovendien leert het ECG ons wat uiteindelijk de werkelijke grootte van het afgestorven gebied is $(16,33)$. De bepaling van de ernst van de schade kan geschieden via speciale ECG-registraties (41-45), via echocardiografie (46), nucleair $(47,48)$ of via bloedonderzoek $(17-19,29,49,50)$. Tenslotte kan ook de prognose op lange temijn via de zojuist genoemde methoden worden bepaald $(51-57)$.

Geinitieerd vanuit Mastricht is vervolgens middels een multicenter onderzoek (de zogenaamde Unasem-studie) nagegaan of fibrinolytische therapie ook bij het 
dreigende hartinfarct, tegenwoordig onstabiele angina pectoris genoemd, zinvol is (58-72). Immers, ook bij dit syndroom worden deels afgesloten kransslagaders gewonden. Deze pilot study, waarin bij iedere patient een hartcatheterisatie werd vernicht, liet zien dat het medicijn inderdaad afgesloten vaten opende. Vaten die bij de catheterisatie al open waren werbeterden echter niet. Helaas bleek het middel de levensverwachting en de complicaties niet gunstig te beïnvloeden, reden om af te zien van een grote studie ( $20 n d e r$ hartcatheterisatie) om het klinische nut van fibrinolytische therapie te bevestigen. In de USA werd een vergelijkbaar onderzoek verricht, met exact dezelfde uitkomsten (73), dat desondanks wél door een groot klinisch onderzoek werd gevolgd - met, zoals te verwachten viel, een negatief resultaat (74). Bij het dreigende infarct bieden fibrinolytica dus kennelijk geen voordelen.

In de jaren daarna is de ingeslagen weg verder gevolgd. Onderzoeken richtten zich onder andere op nieuwe fibrinolytica $(75-90)$. De toch wat verrassende conclusie van al deze onderzoeken is dat er slechts beperkte, weinig spectaculaire verschillen zijn tussen de verschillende middelen. Op dit moment gaat de belangstelling daarom vooral uit nar de combinatie van fibrinolytica en andere medicamenten, de zogenaamde co-medicatie. De eerste studie met co-medicatie hebben we overigens reeds jaren geleden gedaan (91). De meeste van de geteste middelen gaan het samenklonteren van bloedplaatjes tegen, een van de belangrijkste aanleidingen vam het hartinfarct. Aspirine is bijwoorbeeld zo'n middel (92). De eerder genoemde fibrinolytica grijpen niet in op de stolselworming, zij lossem alleen de stolsels op.

Er zijn momenteel overigens veel sterkere medicamenten dan aspirine tegen stolselvarming beschikbaar, zoals de 2b/3a-receptorantagonisten (93-103). Deze stoffen blijken inderdaad gunstig te werken bij zowel het acute infarct als het drejgende infarct. De vraag is of deze stoffen ook in combinatie met fibrinolytica kunnen worden gegeven. De hoop is dat de combinatietherapie nog effectiever is in het openen van het afgesloten bloedvat, en dat een dergelijke nogal agressieve therapie niet leidt tot meer bloedingscomplicaties. De eerste studies laten zien dat met aangepaste doseringen van de verschillende medicamenten goede resultaten te verkrijgen zijn $(93,102)$. De bloeding complicaties zijn in de hand te houden, terwijl er inderdaad meer vaten opengaan. op dit moment wordt daarom wereldwijd onderzocht of de combinatie van een $2 \mathrm{~b} / 3 \mathrm{3}$-receptorantagonist met een fibrinolyticum ook leidt tot betere klinische uitkomsten bij het infarct. 


\section{DOTHEM}

Een geheel andere aanpak om het afgesloten bloedvat bij een hartinfarct te openen is dotteren. Deze behandeling wordt primaire percutane transluminale coronaire angioplastiek (PTCA), ook well dotteren genoemd. Hierbij wordt een ballon in de afsluiting gebracht en opgeblazen om het vat weer doorgankelijk te maken. Een elegante methode die minder risico's op bloedingcomplicaties kent dan de fibrinolytica. Ook op dit gebied heeft Nederland een belangrijke bijdrage geleverd. Bij drie vergelijkbare onderzoeken van drie zeer gemotiveerde researchgroepen werden dotteren en fibrinolyse vergeleken. Dotteren bleek veel beter te zijn (104-106). Later is het onderzoek in andere centra bij een veel grotere patienttengroep herhaald, waarbij de verschillen in de "werkelijke wereld" toch veel minder evident bleken (107).

Een tweede aanpak is uitvoerig in Maastricht onderzocht. Daarbij werd gekozen voor de zagenaamde rescue PTCA, hiermee is dotteren bedoeld na de mislukte fibrinolyse. We gingen ervan uit dat het afgesloten bloedvat zo smel mogetijk moet worden geopend, immers, tijud=hartspier. Zeker's nachts kast het tijd om het dotterteam in huis te halen en de procedure op te starten. Deze wachttijd kan nuttig worden besteed door alvast een fibrinolyticum te geven. Na het starten met dit middel zal bij 60 tot $70 \%$ wan de patiënten het vat binnen zestig minuten weer open zijn; alleen de resterende patiënten behoeven een aanvullende ingreep om het vat alsnog doorgankelijk te krijgen.

Vele anderen hebben deze combinatietherapie verketterd, en wel om twee redenen. Het is naar hun ervaring veel lastiger om het afgesloten bloedvat na mislukte fibrinolyse te dotteren dan bij primaire PTCA, terwijl ook de klinische uitkomsten van rescue PTCA slecht zouden zijn. De resultaten van de Rescue studie bieden erig tegenwicht tegen deze beweringen (108): dit kleinschalige onderzoek liet een (overigens statistisch nihet overtuigende) verlaging van de sterfte en een verbetering van de linkerkamerfunctie zien. Onze ervaringen met rescue PTCA zijn juist uitstekend. In Maastricht zijn meerdere onderzoken uitgevoerd naar de waarde van verschillende fibrinolytica. Een aantal van deze studies vereisten een hartcatheterisatie. Deze werd verricht zestig tot negentig minuten na het starten van het te onderzoeken middel. zo $_{0}$ kon worden vastgesteld of het afgesloten bloedvat inmiddels weer open was $(76$.

HART EN $\mathbb{E} \mathbb{E} E$ 
$80-83,91)$. Na het overwinnen van enge schroom zijn we hele zieke patienten, met nog steeds afgesloten waten, gaan dotteren. De meesten van hen knapten na een geslabgde procedure meteen enorm op, reden om deze therapie meer systematisch te gaan toepassen (109). Inmiddels heeft Maastricht cen uneke serie opgebouwd van 759 patienten die cen van beide dottertherapieen - hetzij rescue PTCA hetzij primaire PTCA - ondergingen (110). Via een tweetal analyses hebben we laten zien dat de kans op het succesvol openeri van een bloedvat na mislukte fibrinolyse vergelijkbaar is met dat van primaire PTCA: bij circa 90\% van de patiënten is de procedure succesvol. De complicaties bij deze infarctpatiēnten na rescue PTCA zijn eveneens vergelijkbaar met die van de primiare PTCA.

Vepgetikng resewe PTCA en prinare PTCA:

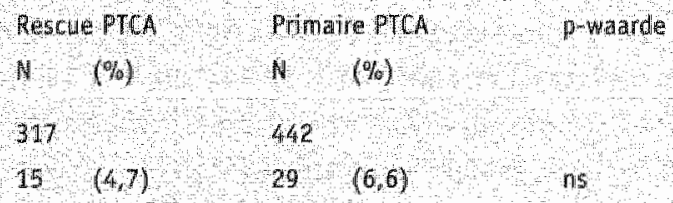

De verklaring voor het verschil tussen onze positieve ervaringen en de negatieve uitkomsten elders is eenvoudig. Het is ons beleid om direct aansluitend aan de mislukte fibrinolyse (na zestig tot negentig minuten) te dotteren. Vele anderen wachten op complicaties om pas dan - en naar onze overtuiging te laat - alsnog een poging te doen het vat te openen. Zoals te verwachten valt zijn de resultaten dan veelal slecht $(54,111)$.

In het eerder genoem de onderzoek (110) waarbij rescue PTCA en primaire PTCA zijn vergeteken, is ook onderzocht of het gebruik van stents (kleine metalen veertjes) na dotteren de uitkomsten verbeterden. Dit kon niet worden aangetoond. Immiddels heeft Mastricht een nieuw grootschalig internationaal onderzoek opgestart warin wij, samen met een groot aantal ziekenhuizen in Europa, Israël en de USA, zullen hagaan of stents een toegevoegde waarde hebben bij rescue PTCA: de helft van de patiënten zal gewoon worden gedotterd, de andere helft van de patiënten krijgt na dotteren een stent. Dit. onderzoek is naar onze overtuiging noodzakelijk, ondat op dit 
moment zonder een goede wetenschappelijke basis in meer dan de helft van de infarctpatienten dure stents worden geimplanteed. Het huidige onderzoek zal uitkomst moeten bieden ten aanzien van de toegevoegde waarde wan de implantatie van stents.

In de afgetopen jaren is wél gebleken dat stents op andere gebieden een belangrijke aanvuling van ons therapeutische arsenaal zijn (112-117). Stents hebben er namelijk voor gezorgd dat we veiliger kunnen werken. Als de dotterprocedure leidt tot een acute afsluiting van het vat kan een stent de bloeddoorstroming weer herstellen. Verder neemt de kans op een nieuwe vernauwing af op de plaats waar gestented is. Als er echter een nieuwe vernawing in een stent optreedt, is deze moejw lijker te behandelen. In Maastricht zijn we erin geslaagd coatings voor de stents te ontwikkelen die dat risico doen afnemen. Deze polymeren kumnen tevens worden geladen met medicamenten om de locale vatwandreactie te verminderen $(118,119)$. Deze coatings zouden bijzonder waardevol kunnen zijn bij het acute hartinfarct, indien ze stolseloplossende stoffen bevatten.

Veel patienten krijgen in de acute fase van het hartinfarct een hartcatheterisatie. Zoals eerder gezegd blijkt dat circa tweederde van de bloedvaten na fibrinolyse weer doorgankelijk is. Vaak blijft er echter een enstige vernauwing over. In de beginjaren ' 80 is daarom in twee studies onderzocht of acuut dotteren bij fibrinolysepatienten zinvol is $(120,121)$. Een goede differentiatie tussen op dat moment al open en nog dichte vaten werd toen niet gemakkt. In deze twee studies kon niet worden aangetoond dat acuut dotteren voordelen bood. Inmiddels is er echter een aanzienlijke vooruitgang geboekt met de kwaliteit van materialen, de kennis rond het dotteren van het acute hartinfarct en de kunde van de cardiologen die de dotters doen. Reden genoeg om ook in deze richting nieuw onderzoek te initiëren. We zullen nagaan of het acuut dotteren van nog open vaten bij infarcten voordelen biedt. Immers, bij goed resultaat is de noodzaak van een nieuwe ingreep in een latere fase van het hartinfarct veel lager. Het opnieuw optreden van pijn op de borst komt waarschijnlijk ook minder vaak voor. Anderzijds is stolselworming in het bloed tijdens de acute fase wan het hartinfarct geactiveerd, hetgeen mogelijk leidt tot meer mislukte dotters. Verder wordt warschijnlijk een fiks aantal patienten gedotterd die het eigenlik niet nodig hebben. 


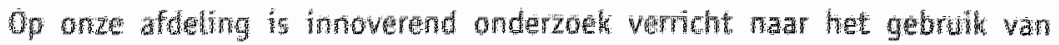

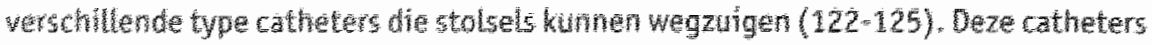

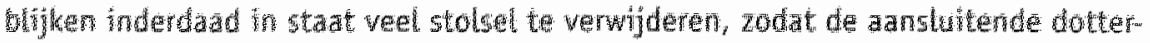

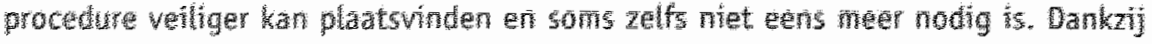

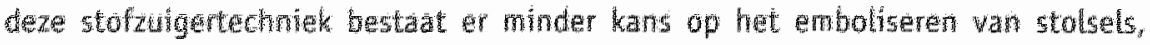
deper de kranstagader in. Deze afzugsystemen zin tevents gesch woor bypasses.

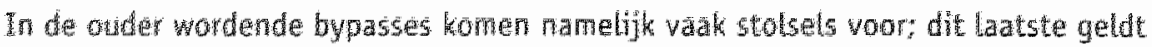
oot voor dialys-shunts en omeidingen in da benen.

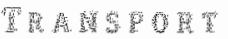

In PrCA-centra zijn zowel fibrinolytische therapie als dotteren mogelijk. Negentig procent van de Nederlandse klineken hebben echter geen eigen dotterfacilteiten en zullen patienten voor eên dergelijke ingreep moeten verwijzen. Hoe zinvol is een dergelijke verwizhng? Door de positieve resultaten van het dotteren (zowel primair als rescue) zijn andere klimieken grote infarcten naar ons gaan verwijzen; in deze regio was het ziekenhuis Sittard de eerste (126). De andere kinieken in Middenen Zuid-Limburg hebben dit voorbeeld al snel gevolgd.

Bij het napluizen van de uitkomsten bleek dat tramsport van patienten met grote infarcten van het ene naar het andere ziekenhuis veilig kan worden verricht, hêtgen een groot compliment is voor de ambulancediensten. Dergelijke achteraf-analyses kunnen sterke aanwijzingen geven of een bepaalde aanpak nut heeft (127), maar voor het harde bewijs blijft nader onderzoek nodig, onderzoek warbij van tevoren is bedacht hoe de aanpak zal zijn en welke gegevens moeten worden verzameld. Dit was de reden on de unieke LImburg Myocardial Infarction studie (LMMI) uit te voeren, tezamen met de vijf andere ziekenhuizen van Midden-en Zuid-Limburg (1.28). In de LIMI werden pattienten met grote infarcten verdeeld over een van de drie volgende behandelstrategieën:

I Fibrinolyse en verdere behandeling in het eigen ziekenhuis; 
II Start fibrinolyse met direct transport naar Mastricht alwaar hartcatheterisatie en zonodig een rescue PTCA (bij een afgesloten vat) werd vernicht;

III Meteen transport naar Maastricht voor primaire PTCA.

Deze studie bevestigde dat transport veilig kan worden uitgevoerd, ook bij patiënten met grote infarcten. Verder bleek dat zowel de ambulancediensten als ook het Maastrichtse PTCA-centrum de extra patiëntenstroom aankonden. Er werden slechts geringe verschillen gevonden in de klinische uitkomsten van de drie strategieën. Anders gezegd, thrombolyse zonder een verdere interventie elders is kennelijk zo slecht nog niet. We moeten ons echter realiseren dat het aantal patiènten in de LIMI zich beperkte tot 224 patiënten. Hierdoor kan geen zekere uitspraak gedaan worden over de vraag welke van de drie therapieën nu de beste is.

LINI-5tudine

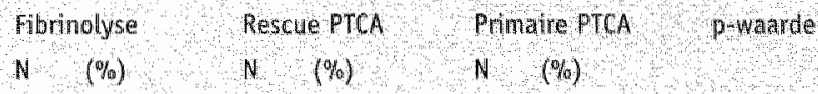

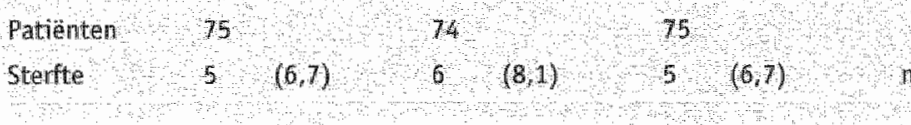

Recent werden de gegevens van de Prague-studie bekend, die een vergelijkbare studieopzet als de LIMI had (129). Hier bleek fibrinolyse veel stechter te zijn dan primaire PTCA; rescue PTCA lag er tussenin. De sterfte in de fibrinolyse-groep was circat tweemaal zo hoog als in de LIMI. Dit kan ofwel betekenen dat de zorg in Nederland een compliment verdient, ofwel dat de zorg elders beter kan; de waarheid is waarschijnlijk een combinatie van beide. Ook heeft een kosten-batenanalyse van de LIMI plaats gevonden: fibrinolyse sec zonder transport is verreweg het goedkoopste. Als echter de complicaties worden meegewogen komen de andere twee strategieën er ook redelijk af.

In dit verband lag het in de bedoeling op een grotere schaal de zogenaamde Holland Infarct Studie ut te voeren. Na twee jaar intensieve arbeid bleek de visie van de potentiéle subsidiegever helas nogal eng te zijn. De watrde, de inhoud en de opzet van de studie was geen punt van discussie. De studie werd echter afgewezen, en

$H A R T E M I E L$ 
well op statistische argumenten: het antal patienten nodig voor de studie zou te laag zifh. Deze unieke an utterst belangrijke studie kon daarom in Nederland geen doorgang vinden: een gemiste kans, Gelukkig voeren onze Deense collega's dit waardevolle anderzock nu uit.

\section{Ant}

Het eerder genoende Sittardse onderzoek liet ook zien dat het gebruik van het ECG, bij het bepalen of het vat zich na fibrinolyse opent, zeer muttig is $(37,126)$. Bij 66 van de 155 patienten, die na het starten van fibrinolyse vanuit Sittard werden doorverwezen yoor een eventuele PTCA, bleek het vat op grond van de veranderingen op het $\mathbb{E} G G$ open te zijn. Reden om de patienten niet te catheteriseren, maar ze meteen weer retour naar het eigen ziekenhuis te laten gaan. Nietéen van deze patiënten overleed tijdens de opname.

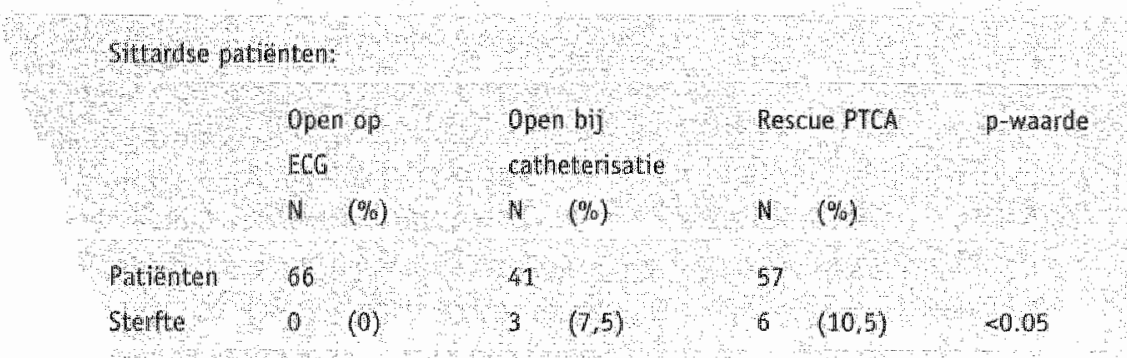

Zeer racent hebben we in een tweede studie exact dezelfde ervaring opgedaan. De patiènten in dit onderzoek ondergingen wél een hartcatheterisatie, waarbij 67 van de 230 patienten bij catheterisatie zowel een redelijke of goede doorgankelijkheid van het infarctwat bleken te hebben alsookeen verbeterd ECG. Reden on deze mensen miet te dotteren. Niemand van deze 67 patiënten is gedurende het eerste jaar na het infarct overleden. Ter vergelijking, de sterfte van de resterende infarctpatienten in dat onderzoek was $6 \%$ (39). 
Uit alle infarctstudies blijkt: tijd=hartspier. Met andere woorden: hoe sneller de kransslagader bij een acuut hartinfarct weer opengaat, hoe kleiner de schade. Als het vat binnen een half uur weer doorgankelijk is ontstaat nauwelijks of geen bescha* diging. Na zes uur is het infarct meestal compleet, dan zal het openen van het vat de infarctgrootte slechts in zeer beperkte mate beinvloeden. Uit (onder andere Noderlands) onderzoek is gebleken dat het geven van een fibrinolyticum thuis of in de ambulance zinvol is om de tijd tot behandeling te bekorten. Dit prehospitaal geven wan fibrimolyse met de daaraan gekoppelde tijdwinst vertaalt zich zoals werwacht in kleinere infarcten en minder doden $(130,131)$. Het goed getrainde ambulancepersoneel gaat bij patiënten met pijn op de borst na of ef contra-indicaties voor fibrinolyse zijn (verhoogde risico's op bloedingen, zoals een maggbloeding in her recente verleden) en maakt een ECG. Het ECG wordt via een computer beoordeeld of ter beoordeling naar het ziekenhuis doorgefaxed. Als er geen contra-indicaties zijn en het ECG een duidelijk infarct laat zien, krijgt de patiënt fibrinolyse. Hoe groter de rijafstanden. hoe groter de tijdwinst, dus hoe groter het verschill qua infarctgrootte ten opzichte van patiënten die deze therapie pas in het ziekenhuis krijgen. Zelfs in Nederland, waar de gemiddelde rijtijd van huis naar het ziekentuis slechts tien à vijftien minuten is, bleek dat de ambulancedienst het fibrinolyticum vijfenveertig tot zestig minuten eerder gaf dan het ziekenhuis. De belangrijkste reden hiervoor is dat men in het ziekenhuis een aantal stappen moet zetten alvorens de medicatie gegeven wordt. De optelsom van de tijd voor deze stappen is aanzienlijk: patiënt moet in bed worden gelegd; het ECG moet worden gemaakt; een arts zal dit moeten beoordelen - wanneer hij tenminste niet elders bezig is; deze arts moet vervolgens nagaan of er contra- indicaties voor fibrinalyse zijn, en de gegevens daama met zijn achterwacht bespreken. Uiteindelijk valt het besluit, maar dan moet de patiënt nog worden ingelicht en de medicatie klaargemaakt. Dan start pas het infuus met fibrinolyse. Aanvankelijk reageerden de meeste klimieken met ongeloof over deze trage afhandeling. Inmiddels hebben veel ziekenhuizen stappen genomen om sneller te handelen. Een tijdsduur van minder dan dertig minuten, van opname tot start van de therapie, is echter nog steeds uitzondering.

HARTENZIEL 
Prehosptate fibrinolyse heeft ook fikse consequenties voor het ambulanceper soneel. Zij zien zeer veel patiënten met pijn op de borst, echter slechts één op de twintig mensen blijkt ook echt sen infarct op het ECG te hebben. Er moet dus veel werk verzet worden am de juiste patienten te selecteren. Indien er echt sprake is van een hartinfarct moet het a mbulancepersoneel de aanwezigheid van eventuele contra-indicaties nagaan, het irfuus klaarmaken en de naald inbrengen, dit alles in suboptimale omstandigheden. Daarna kan de patiẻnt pas op transport.

Een alternatief voor prehospitale fibrinolyse zou het volgende kunnen zijn: de ambulance stelt wia een ECG de diagnose en gat na of er contra-indicaties zijn; deze gegevens geeft het personeel wervolgens aan het ziekenhuis door, dat het fibrinolyticum in de geêigende gevallen klaarmaakt en het middel direct bij binnenkomst toedient. Dit beperkt het werk van de ambulancedienst en zal de vertraging in het ziekenhuis aanzientijk bekorten; het vereist echter zeer goede onderlinge afspraken.

\section{䈍}

Het is het gemakkelijkste om fibrinolytische therapie via één injectie (bolus) te geven (132). Dit is niet alleen zeer praktisch voor de ambulance, het werkt ook tijdbesparend in het zlekenhuis. Tot voor kort kon dit alleen met het middel eminase $(133,134)$. Merkwardig is dat eminase, hoewet het als een van eerste fibrinolytica op de markt kwam, zo weinig wondt gebruikt. Het is namelijk even effectief als het zeer veel gebruikte streptokinase, dat alleen wia een infuus wordt toegediend. Prijswerschillen spelen hierbij slechts cen beperkte rol.; het verschil in populariteit moet aan de marketingstrategie van de farmaceut hebben gelegen. Het voordeel van de unieke doseringswijze van eminase is gewoon onvoldoende uitgebuit.

De laatste tijd zijn er een aantal nieuwe fibrinolytica op de markt gekomen. Sommige van deze stofien kunnen ook als bolus worden toegediend. Dat geldt onder meer voor het in Maastricht geteste middel saruplase. In een pilot study (BASE genoemd) hebben we samen met 8 Europese klinieken onderzoek gedaan naar de beste dosering van dit medicament (135). De $80 \mathrm{mg}$ bolus saruplase bleek even effectief te zijn in thet openen wan het infarctyat als de standaarddosering die via het infuus wordt gegeven. Een grote vervolgstudie in vijfentwintig Europese klimieken (BIRD) liet zien 
dat ook de klinische uitkomsten, bijwoorbeeld de sterte, in beide doseringsschena's vergelijkbaar zijn (136). Recent is aangetoond dat Lanoteplase, een ander fibrinolyticum, ook goed werkt wanneer het als een eenmalige injectie wordt toegediend (137).

BIRD-stude:

Bolus 3 , nulus purarde

$N(\%) \quad+N$

(\%)

Patienten

1196

1212

Sterfle

70

$(5,9)$

13

$(6,0)$

115

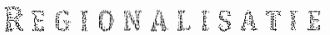

Binnen de cardiologische wereld bestaat consensus dat primaire PTCA een uitstekende behandeling is voor het acute infarct (104-107). Zoals eerder anngegeven zijn de meningen verdeeld waar het rescue PTCA betreft (108-110). Er gaan stemmen op om in zuekenhuizen die momenteel niet dotteren de acute infarcten toch middels PTCA te behandelen. Om financiële redenen, maar vooral vanwege kwaliteitsoverwegingen is dit naar mijn overtuiging echter een volstrekt ongewenste zaak.

Een nieuwe invalshoek is om in een bepaalde regio patiënten met grote infarcten, en dus met het grootste risico van complicaties, direct door de ambulance naar het naburig gelegen PTCA-centrum te laten rijden, en miet naar het dichtstbijzijnde ziekenhuis zonder dottermogelijkheden. De kleinere, minder ernstige infarcten zouden net als voorheen in de miet-invasieve ziekenhuizen moeten worden opgenomen. Een dergelijke regionalisatie legt een fikse claim op het ambulancepersoneel. Zij moeten immers de splitsing maken tussen grote en kleine infarcten. Dit lijkt overi: gens moeilijker dan het is. Hierbij kan grotendeels op het ECG worden vertrouwd. In het algemeen is er bij veel veranderingen op het ECG sprake wan een groot infarct en bij weinig ECG-afwijkingen van een klein infarct. Dit ECG kan, net als bij prehospitale fibrinolyse, via de computer of door het ziekenhuis worden beoordeeld. Afhankelijk

HARTENZIEL 
van de uttkomst zal patient vervolgens naar een algemeen ziekenhuis of een PTCA-centrum worden gebracht. Bijkleine infarcten kan men al in de ambulance fibrinolyse geven, of men warschuwt het ziekenhuis on de medicatie alvast klaar te maken. Mochten er echter contra-indicaties bestaan voor fibrinolyse, dan zou dit eveneens reden kunnen zijn voor rechtstreeks vervoer naar het dottercentrum. Het is warschijnlijk dat een dergetijke gedifferentieerde en tijdbesparende aanpak aanzientijke winst in patientenlevens oplevert.

Een dergelijke regionalisatie heeft uiteraard fikse consequenties voor de patientenstromen, en voor de belasting van ambulances en ziekenhuizen. De complexe patienten komen in de PTCA-centra terecht, die hiervoor vooralsnog onvoldoende bedden en personeel hebben. Deels kan dit worden opgevangen door een zo kort mogelijk verblijf van deze patiënten. Gedotterde patiënten zonder complicaties kunnen bijwoorbeeld snel worden overgeplaatst naar het eigen ziekenhuis. Hierwoor is consensus nodig tussen de cardiologen die in een dergelijke regio werken.

Voor de ambulancedienst heeft zo'n aanpak eveneens nogal wat gevolgen. Ze moet voor vervoer, diagnostiek en selectie zorgen. De ziekste patiënten worden naar een vaak verder weg gelegen PTCA-ziekenhuis gebracht. Bovendien moeten deze patiënten na enige tijjd worden overgeplaatst naar een ziekenhuis elders. Tenslotte: dit alles betekent voor patiënten en familie langere reistijden en contacten met meerdere artsen; dit latste maakt de communicatie moeizamer. Het voordeel is echter dat patienten optimaal worden behandeld.

In Nederland is de werkgroep "Acute Interventies" opgericht om zich over prehospitale diagnostiek en optimale therapie te buigen. De werkgroep zal verder pogen het Nederlandse dotterbeleid eenduidiger te maken en eventuele controversen uit de weg te ruimen. Deze werkgroep zal tevens wetenschappelijk onderzoek in bovengenoemde richting stimuleren.

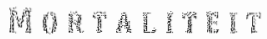

De Maastrichtse belangstelling voor het hartinfarct heeft zich ook gericht op cle sterftecijfers, welke ten gevolge van het veranderend infarctbeleid in de loop der jaren aanzienlijk zijn gedaatd. In de zestiger jaren was de ziekenhuissterfte nog $29 \%$ : 
deze zakte dankzij de CCU's in de zeventiger jaren geleidelijk tot $21 \%$. De levensverwachting van de Maastrichtse patienten met een infarct is nauwkeurig onderzocht woor de jaren 1982, 1988 en 1994 (138-142). In 1982 was infarctbeperking, fibrinow lyse of dotteren in Maastricht nog niet aan de orde, alleen de complicaties van het infarct werden behandeld. De sterfte van infarctpatiènten in Maastricht lag toen op $17 \%$. Deze daalde spectaculair tot $10 \%$ in 1988 en $9 \%$ in 1994 . De winst na 1982 komt geheel op het conto van de agressieve aanpak on de kiansslagader weer zo snel mogelijk na het begin van het infarct te openen.

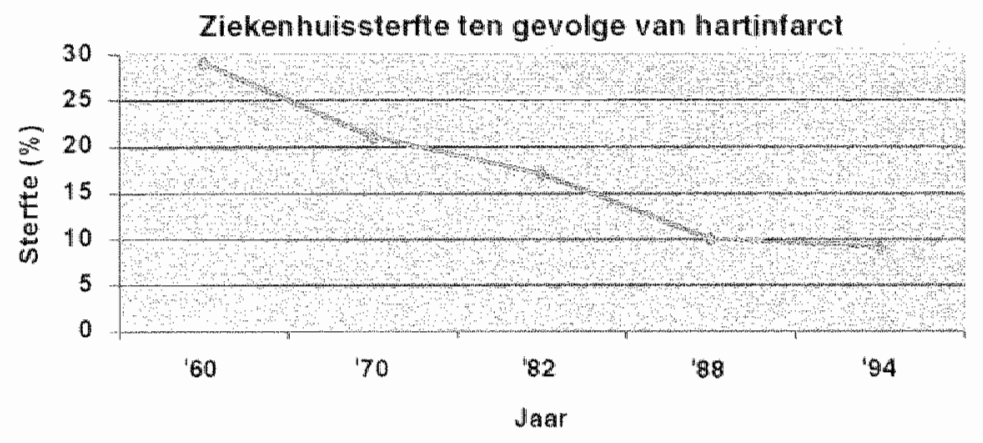

Zoals eerder aangegeven is kamerfibrilleren de belangrijkste complicatie van het acute hartinfarct. Deze ritmestoornis kan tot plotse hartdood leiden (143-146). In Zuid-Limburg is de plotse hartdood in de periode vam 1991 tot en met 1995 zorgvuldig geëvalueerd $(147,148)$. Jaarlijks overlijdt één procent van de mensen tussen de 20 en 75 jaar plots, dit is eenvijfde van de totale sterfte in deze leeftijdscategorie. De mensen overlijden meestal thuis en meestal in rust. De in verhouding kleine groep hartpatiënten heeft een elf keer hogere kans op plotse dood dan de veel grotere groep van mensen die van tevoren niet met een hartziekte bekend was. Bij sectie bleek dat het hart inderdaad de doodsoorzaak was bij driekwart van alle mensen die plots overleden.

Ook na de acute fase van het hartinfarct kan de ritmestoornis kamerfibrilleren optreden, het betreft dan vaak een groot infarct (149-153). Het kamerfibrilleren wordt meestal woorafigegaan door een aanval van snelle hartkloppingen (kamertachycar-

HARTENZIEL 
dièen). Ook dit kan leiden tot plotse hartdood. Gezien de belangstelling van de Maastrichtse kitniek voor nitmestoornissen is ook aan kamerfibrilleren veel onderzoek gespendeerd. Het elektrofysiologisch onderzoek speelt daarbij een belangrijke rol. Dit is een catheteronderzoek warbij wordt gepoogd de ritmestoomissen via een soort pacemaker op te wekken en weer te stoppen. Jarenlang is de therapie van genoemde ritmestoornissen medicamenteus geweest. Deze aanpak blijkt echter vaak te falen, reden om nieuwe wegen te bewandelen. Soms is het mogelijk de ritmestoornissen te behandelen door middel van de zogenaamde ablatie. Via een catheter wordt dan het gebledje in het hart weggebrand dat de oorzaak van het probleem is. Meestal is echter een speciale pacemaker nodig (defibrillator) (154). Deze is in staat de ritmestoornissen te herkernnen en middels een elektrische schok te stoppen: een zeer adequate maar kostbare therapie.

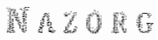

De angst is nogal wat hartinfarctpatienten letterlijk en figuurlijk om het hart geslagen. Ze durven niets meer of worden sterk beknot door hun familie, reden om hier extra aandacht aan te besteden $(10,11)$. In de kliniek wordt middels goede voorlichn ting aan de patiënt door artsen, verpleegkundigen en fysiotherapeuten gepoogd deze angsten te doorbreken (155-161). In Maastricht hebben we er verder voor gekozen onze poliklinische patiërten bij één vaste cardioloog te laten terugkomen. Dit is naar mijn mening een premisse voor goede begeleiding. Hiertoe het volgende voorbeeld:

Een vijftigjarige man bezocht mijn spreekuur. Hij was vier weken tevoren op de afdeling cardiologie opgenomen geweest met een acuut infarct. Woordien had hij geen hartklachten, wel had hij al jaren steken links op de borst. De laatste maanden klaagde hij over moeheid waarvoor hij geen verklaring wist. Hij kon zijn werk als bankbediende temauwernood aan. Daarom had hij na lang aandringen van zijn vrouw de huisarts geconsulteerd. Deze kon verder niets bijzonders vinden; hij adviseerde patiënt minder koffie te drinken en zich wat minder druk te maken over zijn werk en de kinderen. De dag voor opname had hij in rust kortdurende aanvalletjes van druk op de 
borst. Aangezien hij wat verkouden was geweest weet hij zìnn klachten hieraan. De volgende dag echter ontstond bij het opstaan een heftige pijn die niet meer over ging. Zijn wouw bemerkte dat hij er beroerd nitzag en belde tegen zijn zin de huisarts. Deze waarschuwde de ambulance. Bij binnenkomst in het ziekenhuis bleek hij een groot voorwandinfart te hebben. Aangezien de catheterisatiekamer op dat moment wij was werd besloten tot een primaire PTCA van de afgesloten kransslagader, die succeswol was. De andere kransslagaders lieten wat wandonregelmatigheden zien met, op één plaats in een kleinere tak, een vermawing van circa $70 \%$. De grootte van het hartinfarct viel door de snelle behandeling mee. Tijdens opname had patiënt nog regelmatig de bekende steken op de borst, maar miet meer de druk zoals bij het hartinfarct. De linkerkaner-restfunctie was goed. Het inspannings-ECG toonde een goede inspanningstolerantie, er waren geen aanwijzingen voor zuurstoftekort van het hart. Hij werd verwezen naar de poliklinische cardiorevalidatie. Bij het eerste polikliniekbezoek bleek patiënt alleen te zijn. Mijn vraag waarom zijn vrouw niet was meegekomen werd geantwoord: "Ik heb toch het infarct gehad?" Bij navraag bleek patiënt wel nog de bekende steken te hebben, maar geen druk meer te woelen. Dok andere hartklachten ontbraken. Van wandelen kwam nog niet veel, "het weer was ook zó slecht". Dok thuis kwam hij tot niets. Tegen het hervatten wan het werk zag hij als een berg op. Het roken had hij inmiddels met veel moeite gestopt, maar hij hield het vol! Het verder onderzoek en het ECG leverden geern nieuwe bijzonderheden op. Na de opname en de huidige klachten te hebben besproken, werd ingegaan op het risicomanagement (in zijn geval permanent stoppen met roken, stressreductie en cholesterolbehandeling). Hij was opgelucht door de herhaalde mededeling dat de steken geen relatie hadden met het hart. De in het ziekenhuis ingestelde medicatie kon hij overigens goed verdragen. Hij wilde wel werken maar zag dit vooralsnog niet zitten: veel te veel stress. Bovendien, zijn chef had tot nu toe slechts éenmaal naar zijn gezondheid geinformeerd. Afgesproken werd dat hij bij de volgende controle zijn echtgenote zou meenenen.

Tijdens het tweede bezoek richtte ik mij als eerste tot de vrouw, met de vraag hoe het met haar ging. Ze was verbaasd en meende dat ik mij vergiste:

HARTENZIEL. 


$$
\begin{gathered}
\text { "Een goede anamnese } \\
\text { is hat halve merk" }
\end{gathered}
$$

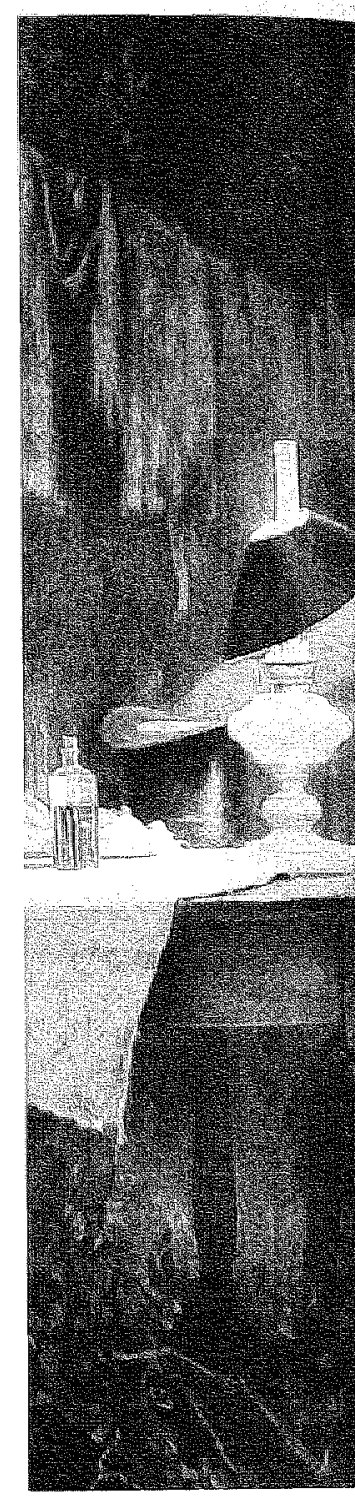

INAUGURELEREDE 


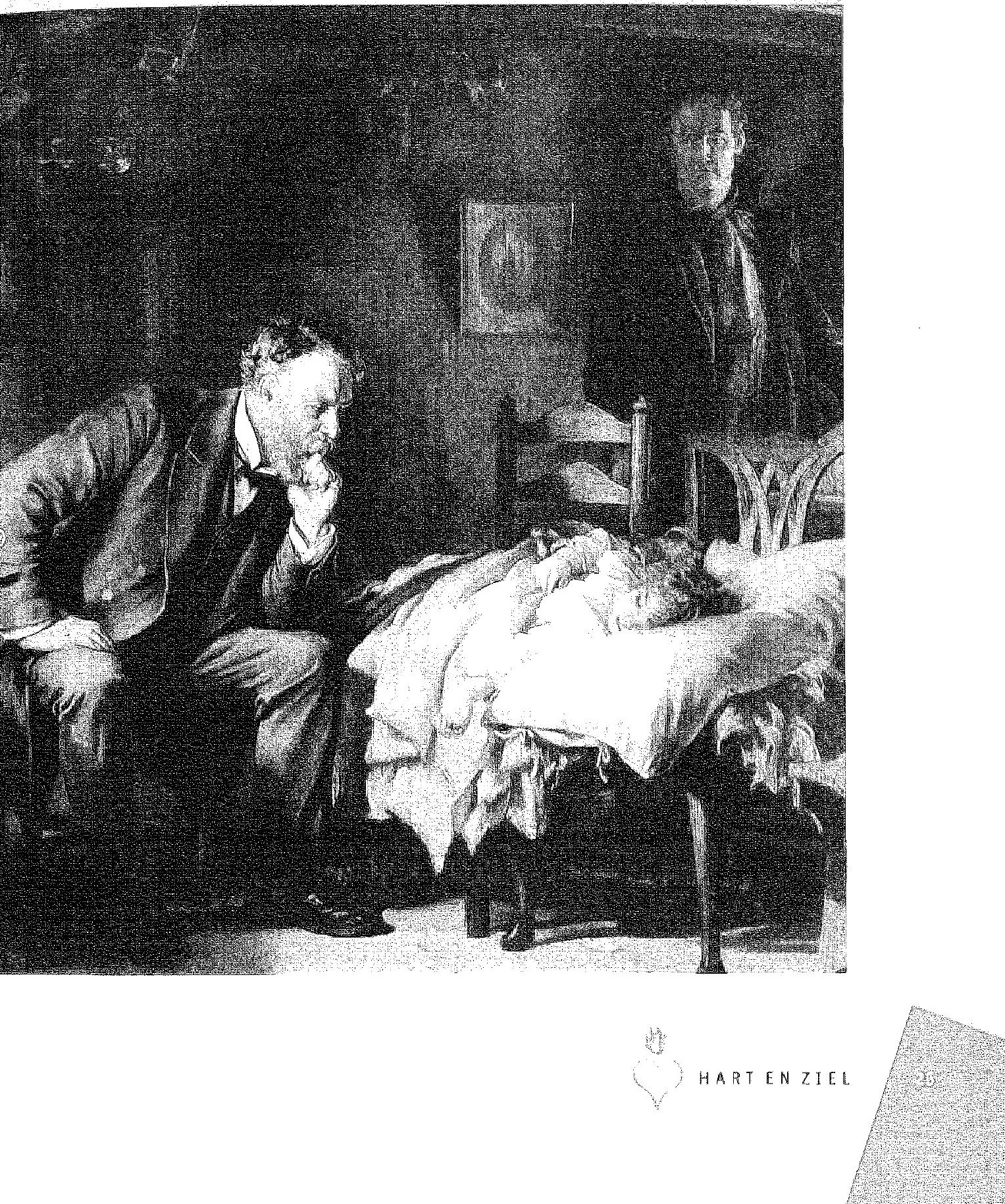


niet zif mar haar man was de patient. Hij bleek this vanwege agressief gedrag naw welijks te handhaven; dan weer zei hij dagen bijna niets of was uren van huis weg, zodat zijn vroww het ergste vieesde. 's Nachts sliep ze nauwelijks, ze bleef luisteren of hij nog wel ademde. Ze was vooral angstig vanwege de resterende $70 \%$ vemauwing, en vreesde dat het leder moment weer zou misgaan. De echtgenoten bleken hun gewoelens thuis voor elkaar te verzwijgen, dit om de ander te sparen.

Bif patienten met een hartinfarct behoren in gesprekken een aantal aspecten aan bod te komen: de toestand van het hart, de psychische toestand van patiënt en partner, en verder de medicatie, risicofactoren en het werk $(10,11,162,163)$. Helaas bestatat de neiging bij artsen zich grotendeels te concentreren op thet hart, en de ziel te negeren. Bewustwording van dit manco zou een groot goed zijn.

Hierbij komt: de taal van de dokter is meestal niet de taal van de patiënt. Ook dit zou in de opleiding veel meer aandacht mogen krijgen. Niet zelden snijden artsen onderwerpen aan die voor de patiënt irrelevant zijn. Anderzijds blijken veel patiëntem zich nauwelijks of niet voor te bereiden op het gesprek met de arts, ze wachten passief af wat komt. Dit is niet bevorderlijk voor een goede communicatie en een evenwichtige relatie tussen de arts en de patient. Zonder voorbereiding zal de patiënt bovendien veel minder onthouden wan het gesprek. Op de polikliniek is inmiddels een poging tot verbetering van de attitude en de bewustwording van de patient ingezet.

Voor de opvang na het infarct is hartrevalidatie zeer waardevol, het is een inmiddels bekend hulpmiddel om de begeleiding verder te verbeteren. Door oefeningen, sport en spel krijgt de patiënt (en zijn familie) weer vertrouwen. Tijdens de revalidatie worden in gespreksgroepen allerlei onzekerheden en problemen aangekaart - dit met aangetoond nut (164). Dankzij de revalidatie verbetert de resocialisatie, vooral bij alleenstaanden. Bij complexe patienten is klinische revalidatie zinvaller (165-168). De rol van de huisarts bij deze begeleiding moet niet worden onderschat $(11,169)$.

Daarnaast is secundaire preventie belangrijk om mieuwe cardiale incidenten zo lang mogelijk uit te stellen. Naast medicamenten die het leven verlengen, zoals de cholesterolverlagers, moet de patiënt risicovol gedrag vermijden door bijvoorbeeld te 
stoppen met roken. De eerste maanden na het infarct zijn patiënten in het algeneen bereid hun leven te beteren, want de schrik zit er diep in. Daarna komt er vaak de klad in. Maastrichts onderzoek heeft aangetoond dat hartrevalidatie helpt om risicogedragingen ook op langere termijn gunstig te beïnvloeden $(162,163,170,171)$.

Al deze verbeteringen in zorg en begeleiding van patiènten vergen echter tijd, tijd die steeds schaarser wordt.

\section{H}

Om patienten goed te kunnen begeleiden is tijd nodig. De tijd die artsen aan patiënten kunnen besteden komt echter steeds meer in het gedrang. De huidige tendens, deels door de overheid afgedwongen en deels het gevolg van maatschappelijke ontwikkelingen, is namelijk een steeds kortere werkweek woor artsen in loondienst. Het rigide overheidsbeleid leidt ertoe dat voor assistenten ingewikkelde schema's moeten worden gemaakt, opdat ze vooral niet langer dan 48 uur per week in de kliniek aanwezig zijn. De gemiddelde werktijd van academisch specialisten is overim gens (zonder discussie) gemiddeld 55 uur per week. De overheid probeert kennelijk via deze weg meer grip op de specialisten te krijgen en accepteert de desastreuze gevolgen hiervan. Dit opgedrongen beleid leidt tot frequente wisselingen van de wachí. Patiënten krijgen tijdens een week opname niet zelden drie of vier verschillende assistenten aan bed. De tijd die nodig is voor overdracht gaat af van de tijd die aan de patiënten kan worden besteed. Bovendien gaat bij redere overdracht kennis vertoren.

Door de arbeidstijdverkorting dreigt nu een tekort aam personeel te ontstaan. Hierdoor gaan steeds meer ziekenhuizen ertoe over arbeidsintensieve afdelingen buiten kantooruren te sluiten. De specialisten zijn uiteraard weer de boosdoeners: $z i j$ zouden de assistenten uitbuiten en chanteren met hun opleiding. Zelfs als dit hier en daar het geval is, dan is het nog niet de oorzaak van het tekort aan persomeel. Het blijkt namelijk niet mogelijk te zijin voldoende assistenten aan te trekker.

Ook de waag aan de gezondheidszorg neemt toe ten gevolge van de vergrijzing van de bevolking. Verder worden artsen steeds meer managerstaken opgelegd. De wetgeving (BIG-wet) stelt bovendien steeds meer eisen a an artsen ten aanzien van de

HARTEN $21 E L$ 
verslaglegging, maar ook ten aanzien van woorlichting aan de patient atvorens hij of zij een onderzoek of behandeling ondergat. Deze voorlichting is overigens een taak die tenminste gedeeltelijk aan paramedici kan worden gedelegeerd.

Ook de verwachtingen en eisen van patienten stijgen. Patiënten klagen steeds vaker bij de tuchtraad of andere instanties. Deze toename wordt, in het algemeen, niet veroorzaakt door slechter werk van de arts, maar wooral door de tijdsgeest warin (te) veel van anderen en (te) weinig van zichzelf wordt geëist en verwacht. Het is onze verplichting patiënten voor te houden dat we een gedeelde verantwoordelijkheid hebben. Ook zij zullen, om beter te worden, hun bijdrage moeten leveren. De druk die op artsen wordt gelegd leidt in toenemende mate tot defensieve geneeskunde, hetgeen nog veel slechter is voor de patient en veel geld kost: er worden onnodige onderzoeken gedaan om verwijten achteraf te voorkomen. Veet van de klachten van de patiënten zijn terecht, maar zeker evenveel zijn volstrekt uit de lucht gegrepen. In een complex proces als de geneeskunde is er altijd wel iets dat beter had gekund. Onterechte klachten kosten echter handen wol verknoeide tijd en leiden tot enorme frustraw ties bij de aangeklaagden. Niet voor niets zien we een toename van het aantal "burn outs" in de gezondheidszorg. Verhaal op de klager in geval van een onterechte claim is tot dusverre "not done". Helaas begrijpen politici en pers deze ernstige ontwikkelingen niet, of ze willen deze niet begrijpen. Het ergste is dat het bovenstaande zeer bedreigend is woor het bijzonder goede niveau dat de gezondheidszorg in Nederland tot dusvere had.

\section{We row}

Mijn verwachting is dat, bij hartinfarcten, relatief weinig winst te behalen valt met steeds complexere medicamenteuze regimes van allerlei stolseloplossende stoffen. Tevens zullen vele tienduizenden patiënten nodig zijn om zulke verbete ringen wetenschappelijk aan te tonen. Deze "fine tuning" van therapieen is bovendien zeer kostbaar. Op dottergebied lijken de vragen zich wooralsnog te beperken tot de toegevoegde waarde van stents bij het hartinfarct. In thet verkorten van de tijd tussen klachten van sen hartinfarct en therapie zitten zeker nog interessante mogelijkheden. Een maximale verkorting in behandeltijd, bijvoorbeeld door regionalisatie, verlagt 
de sterfte warschijnlijk veel meer dan alle dure mieuwe medicijnen tezamen kunnen bereiken.

Een nieuwe invalshoek is het voorkomen van hatspierschade ten gewolge van het opengaan van het bloedwat. Bij circa $25 \%$ van de patiënten blijkt dat het $E C G$, na het openen van het vat, in plaats van verbetering juist verstechtering laat zien; bovendien hebben deze patiënten veel meer pijn. Deze en andere bevindingen suggereren dat, na het opengaan, het verse bloed de hartspiercellen met zuurstoftekart nog verder beschadigt. De patient komt zo van de regen in de drup. Er loopt al jaren dierexperimenteel onderzoek naar het voorkomen van deze zogenaamde reperfusieschade. Er zijn inmiddels allerlei medicamenten gevonden die de reperfusieschade kunnen beperken of voorkomen. Sommige van deze stoffen zijn gericht op het herstel van de onbalans in de elektrolyten, andere richten zich op het beperken van ontstekingsreacties. Helaas zijn deze stoffen alleen effectief indien ze gegeven worden vóórdat het wat afsluit. Bij de mensen met een infarct zullen we dus meestal te laat zijn. Vrij recent is gebleken dat bepaalde stoffen toch werkzaam zijn als ze na het ontstaan van de afsluiting worden toegediend $(172,173)$. De eerste resultaten met deze medicamenten bij infarctpatiënten zijn bemoedigend. Dergelijke therapieën kunnen de hartspierschade bij het acute infarct nog verder beperken, en zo de levensverwachting verbeteren.

Een zeer interessante ontwikkeling ligt op het vlak van de moleculaire cardiologie (174-176). Een aanzieniijk deel van de Nederlandse bevalking - met sommige politici voorop - staat erg huiverig tegenover genetisch onderzoek. Deze negatieve reactie op vernieuwingen is overigens door de eeuwen heen standaard. Tedere nieuwe ontwikkeling heeft uiteraard zijn keerzijde en zal potentieel schadelijke elementen bevatten, maar dit mag geen reden zijn voor een boycot, eerder voor zorgvuldige evaluatie. Dit geldt ook voor genetische manipulatie, immers de kans op een enorme gezondheidswinst is groot. De meeste mensen realiseren zich miet dat een aantal van de huidige fibrinolytica en andere dagelijks gebruikte medicamenten al lang dankzij genetische manipulatie van bacterièn worden vervaardigd.

Een spectaculair voorbeeld is de behandeling met genetische gemanipuleerde stoffen van patiënten met zeer ernstige vormen van bloedvaatvernauwing. In dit geval gat het om stoffen die de groei van nieuwe bloedvaten beworderen (de zogenaande groeifactoren). Deze stoffen bevorderen de groei van de bloedvaten in het embryo.

HARTENZIEL 
Prof Isner uit Boston gaff dergelijke medicijnen aan patiënten met zeer ernstige bloedvalvernawing in de benen $(177,178)$. Deze therapie leverde verbluffende resultaten op. Bisj vele patienten verbeterde de doorbloeding van het behandelde been binnen een parar maanden sterk, zodat de open en necrotische wonden genazen en patienten weer konden wandelen zonder te worden geplaagd door pijn in de kuiten (etalageziekte). Deze groeistoffen kumnen ook direct in de kransslagaders worden gespoten: misschen zijn ze everiwel weiliger en effectiever als ze, al dan niet na voorafgaand Laseren van de hartspier rechtstreeks in de hartspier zelf worden gernjecteerd. Een dergelijke therapie zou mogelijk echter de kans op kanker kunnen vergroten. Zorgvuldig en intensief onderzoek, ter evatuatie van dergelijke zeer nieuwe therapie vormen, is daarom nodig (179-189).

Allerlei ziekten blijken genetisch bepaald. Ook bloedvatvernauwing is een ziekte warbij erfelijkheid een rol speelt. Het herkennen wan de ziekmakende genen is een eerste stap in deze richting. Ons ziekenhuis doet veel onderzoek naar deze nieuwe vorm van diagnostiek. Maar met diagnostiek alleen zijn we er nog niet: of de ziekte te behandelen is door het gen te veranderen is voorlopig nog onduidelijk. Toch maken we vorderingen; onlangs zijn de eerste studies gestart waarbij gepoogd wordt de zieke genen te vervangen.

We zitten in het kennistijdperk, waarbij dankzij de moderne computerfaciliteiten een fascinerende evolutie plaatsvindt in de snelheid van communicatie en in de mogelijkheden om deze informatie te verkrijgen en te gebruiken. Deze technologie zal de dokter steeds meer gaan ondersteunen in zijn gegevensverzameling en -verwerking. Zo worden binnenkort onze catheterisatiekamers gedigitaliseerd. Dit schept de mogelijkheid de uitkomsten van de onderzoeken snel en zeer accuraat te beoordelen. Deze gegevens zijn daarna op vele platsen, zoals in de polikliniek, opvraagbaar. Aldaar kunnen de films via de computer aan de patient worden getoond. Het is in principe zelfs mogelijk hun een cd-rom mee te geven zodat ze thuis in de huiskamer nog

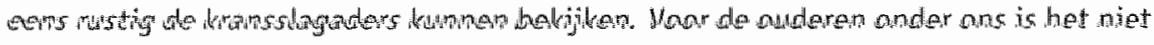
altijd even eenvoudig de technologische ontwikkelingen te wolgen. De meesten van ons typen nog met twee vingers en overzien het enome aanbod aan mogelijkheden nauwelijks. De jongere collegae kunnen al niet meer zonder deze technologie. Sommige van onze patiënten benuten de moderne communicatiemiddelen reeds om 
tot zelfdiagnoses te komen, behandelingsmogelijkheden te ontdekken en succeskansen van therapieèn te bepalen.

Ik heb geprobeerd $u$ te schetsen hoe boeiend de cardiologie is geweest gedurende de vijfentwintig jaar dat ik cardioloog ben. We staan evenwel aan het begin van een nog interessantere periode, waarbij het zeer wel mogelijk is dat bepaalde hart-en vaatziekten kunnen worden genezen. Wie weet zal in de toekomst dotteren en opereren niet meer nodig zijn, of tenminste op veel geringere schaal. Een injectie met: een groeistof, wardoor zich nieuwe, goede bloedvaten ontwikkelen is misschien al voldoende. Werkelijkheild of fictie, de toekomst zal het leren.

Cardiologie blijft een vak om het hart aan te verpanden. Ik zal daarom met hart en ziel doorgaan. 
Mignheer de rector Magnificus, dames en heren.

Via deze weg wil ik allereerst mijn erkentelijkheid uitspreken jegens degenen die achter mij zijn gaan staan om deze benoeming te realiseren. De benoeming heeft plaatsgevonden onder de vleugels van de stichting "Sint Amnadal", en haar geldt dan ook in de eerste plaats mijn dank. Een dergelijke taak brengt verplichtingen met zich mee, maar ik neem wolgaame de uitdaging aan het onderzoek op het gebied van de invasieve tardiologie in Mastricht verder uit te bouwen.

In 1977 ben ik samen met mijn leermeester Hein Wellens naar Maastricht gekomen. Dankżj de steun van onze patiënten mochten we blijwen. Beste Hein, we hebben goede en slechte tijden gekend. Ik heb veel van je geleerd. Wat ik vooral in je bewonder is je enorme vakkennis, je wetenschappelijke belangstelling en je didactische gaven. Hiermee heb je de gezondheidszorg en de wetenschap in Mastricht op hoog niveau gebracht. Je hebt een afdeling opgebouwd waarvoor geldt: "omdat je het kent, herken je het". Met jou aan het stuurwiel is cardiologie een eenvoudig vak.

Een benoeming als deze is niet alleen een honorering voor de kandidaat, maar zeker ook voor degenen die zijn wetenschappelijke activiteiten steunden. Hierbij denk ik uiteraard in de eerste plaats aan alle stafleden en assistenten van de afdeling cardiologie in Maastricht, die ieder op eigen wijze hun bijdrage hebben geleverd. Verplichtingen woel ik vooral in de richting van mijn collegae catheteriseurs, die waak bij nacht en ontij werden opgeroepen om bij infarctpatiënten te interveniëren. Jullie nachtelijke escapades zijn zeer wruchtbaar gebleken.

Verder hulde aan allen die behulpzaam waren bij het bedenken, het uitvoeren en het rapporteren van onze research. Het betreft hierbij overigens niet alleen de eigen groep, maar ook een aantal anderen buiten de cardiologie, waarmee ik op aangename wijze mocht samerawerken. Mogen we zo doorgaan!

Beste Appels, warde Ad, jij hebt me geleerd dat ziel en hart één zijn. Door jouw originele benadering van de medische psychologie ben je een echte bruggenbouwer.

Hartcatheterisatie en dotteren voeren we uit samen met anze hartfunctielaboranten, een ondergewaardeerde groep die echter onmisbaar is voor ons werk. Dit geldt 
eveneens voor de verpleegkundigen, onze research-assistenten en niet te wergeten de aanstormende garde: de student-assistenten.

In acute situaties mogen we altijd een beroep doen op onze cardiochirurgische afdeling, een hele geruststelling op moeilijke momenten. De cardiorewalidatieafdelingen vam Maastricht en Hoensbroek wil ik bedanken voor onze jarenlange voorbeeldige samenwerking tot profijt van velen.

Het secretariaat en in het bijzonder mevrouw Dirkx, onze lieve Margriet, mag zeker niet vergeten worden. Lof komt jullie toe, ik ben overigens van plan het jullie ook in de toekomst lastig te maken. Lieve polikliniekdames, veel dank voor de steun in de afgelopen jaren en zeker ook voor de koffie.

Financiële middelen voor onderzoek zijn schaars, onze afdeling heeft mede dankzij de industrie de mogelijkheid gekregen zich verder te ontwikkelen. Ik wil de betrokkenen hienoor via deze weg credit geven. Dit geldt eveneens voor de leden van het bestuur van de stichting "Hartsvrienden Rescar", maar evenzeer voor alle donateurs, die zich al vele jaren inzetten om onderzoek op het gebied van het hart in Maastricht te stimuleren.

Helaas kunnen ma en mijn schoonouders dit niet meer meemaken. Maar Bär, beste $\mathrm{Pa}_{\mathrm{f}}$ jij had vele jaren geleden een dergelijke post kumnen bezetten als je niet, door de omstandigheden gedwongen, huisarts was geworden. Ik weet dat deze benoeming je heel veel deugd doet.

De laatsten zullen de eersten zijn. Lieve Mitzi en mijn lieve kinderen Jeananne, Jim, Niki en Ginger: jullie hebben me gesteund in soms roerige dagen, en waren bereid me te delen met "het ziekenhuis". Hopelijk zijn jullie beretrots op mij, ik ben het zeker op jullie. Het geduld is toch beloond. Laten we er samen van genieten. 
1 Enthoven W. Die galwanometrische Registrirung des menschlichen Electrokardiogramms, zaglench eifie Beureilurg der Arwendung des Copilaralektrometers in der Psychologie. Plugers Archl, $1903 ; 99: 472$.

2 Wenckebach KF. Die Arhythmie als Augdruck bestimmter Funktionsstoinungen des Herzens. Engetmann, Leipzig, 1927.

3 Doevendane PA, Daemen Muinckd $E, 5$ mits J. Cardiovascular phenotyping in mice. Cardio vasc Res 1998; 39:34-49.

4 Bar JFL, Appets AP, Bár FW: Ontstekingen en vitale uitputting bij patienten met coronariaHigder. Hartbulletin 1998:29:103-6.

5. Cheriex EC. Cardiological aspects of pulmonary embolism. Thesis. Mastricht; 1997.

6 Jansen EW, Janssen J, Cheriex EC, Penn OC. Use of a removable wen cawal filter for prevention of recurrent embolism after emergency pulmonary embolectomy. Tex Heat $31990: 16: 15-7$.

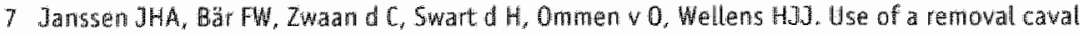
filter for prevention of recurrent pulmonary embolism: A flexible approach. In: Intersive and Critical Care Medicine, Elsevien Science Publishers BV, 1990;1311-3.

8 Sreeran N, Cheries EC, Smeets JLKM, Gorgels APM, Wellens HJJ. Value of the 12-lead electrocardiogram at hospital admission hn the diagnosis of pulmonary embolism. Am J Cardiol $1,994: 73: 298-303$.

9 Levine SA, Lown B. "Arm-chain" treatment of acute coronary thrombosis. Am Heart $J$ $1952 ; 148: 1365-70$.

10 Bär FW, Falger P. Hartrevalidatie. In: Roelandt JRTC, Lie KI, Wellens HJJ, Werf F w (red). Leerboek cardiologie. Houten/Diegem: Bohn Stafleu Vam Loghum, 1995:609-17.

11 Bar FW, Whek JFM, Erdman RAM. Rewabidatie bij patienten met hattafwijkingen. In: Prins $A_{\text {, }}$ Verheugt FWA (red.). Cardiologie. Houten/Diegem: Bohm Stafleu Van Loghum, 1998:183-94.

12 Durrer D. Tweel wd UA. Excitation of the left wentricular wall of the dog and goat. Ann MY Acad Sci $1957: 65: 779$.

13 Durrer 0 . The human heart: some aspects of its excitation. Transactions and studies of the normal rythm. College of Physicians of Philadelphia, 1966;33(3):159-70.

14 Rentrop P, Blanke H, Marsch KR, et al. Acute myocardial infarction: intracoronary application of nitroglycerin and streptokinase in combination with transluminal recanalization. Clin Cardiol $1979 ; 2: 354$

15 Fibrinolytic Therapy Tratists (FT) Collaborative Group. Indications for fibrinotytic therapy in suspected ancutemyocardial infarction: Collaborative overview of early mortality and major morbidity results from all randomized trials of more than 1000 patients. Lancet $1994: 343: 391-22$,

16. Bar $F$, Varmeer $F$, Zwaan d $C_{\text {s }}$ at. Value of admission electrocardiogram in predicting outcone of thrombolytic therapy in acute myocardial intarction. A randomized trial 
conducted by the thetherlands Interuniversity Cardiology Institute. An I Cardiol $1087,59: 6-13$.

17 Laarse wd A, Kerkhof PL, Wemeer F, Sernys PW, Hemens WT, Werhengt FA, Bär PW, Krauss XH, Wall wo $E$ simoons ML. Relation between inferct size and left ventrictar performance assessed in patients with first acute myocardial infarction randonized to intracoronary thrombolytic therapy or to conwentional treatment. An 3 Cardiol 1988;61:231.5.

18 Laarse vd $A$, Wall wd $E$, pol wd $R$, Vermeer $F$, Verheuge FW, krauss XH Bair FW, Hemens W. Willems $G$. Simoons ML. Rapid enzyme release from acutely infarcted myocandiutitafter early thrombolytic therapy: washout or reperfusion damage? Am Heart $11989 ; 15: 711-6$.

19 Laarse wd A, Vermee F, Hermens WT, Willems $6 M$, Neef $d K$, Simoons ML. Serruys PW, Res JC, Verheugt FW, Krauss XH, Bär FW, Zwan d C Lubsen J. Effects of early intmaconom streptokn mase on infarct size estimated from cumulative enzyme release ard on enzyme release rate. Am Heart J 1986;112:672-81.

20 Serrays PW, Simoons ML, Suryapranata $H$, Vermeer F, Wijns W, Brand wd MB, Bär FW, ZWaanan w. Krauss. XH, Remme WJ, Res JC, Verheugt FW, Domburg v R, Lubsen J. Hugenholtz PG. Preserwa tion of global and regional left ventricular function after early thrombolys is in acute myocato dial infarction. J Am Coll Candiol 1986:7:729-42.

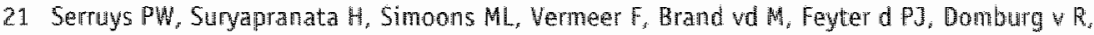
Laarse wd A, Bar FW, Verheugt FW, Res JC, Remme WJ, Zwaals d C, Hugenhola PG. Intracoro rary thrombolys in in patients with acute myocardial infarction: The Netherlands andomized Trial and current status. Circulation 1987,76:5uppl II:63:78.

22 Simoons $M L$, Serruys PW, Brand vd M, Res J, Verheugt FW, Krauss XH, Remme Wy, Bar FW, Zwaan $d C$, Laarse wd $A$, Vemeer F, Lubsen J. Early thrombolysis in acute myocardiat infarction: Limitation of infarct size and improved sumival. I Am Coll Caroiol 1.986;7:917-28.

23 Sinoons ML, Brand wd M. Zwaan d C, Verheugt FW, Remme WJ. Serruys PW, Bär FW. Res J, Krauss XH, Vermeer F. Improved survial after early thrombolysis in acute myocardiat In farc tion. Lancer $1985: 578-81$.

24 Simoons ML, Vos J. Tyssen JGP, Vermeer F, Verheugt FWA, Krauss XM, Manger Cats $V$. Long-term benefit of early thrombolytic therapy in patients with acute myocardiallinfarction: 5 year follow-up of a trial conducted by the Interuniversity Cardiology Institute of the Mether lands. J Am Coll Cardiol 1989;1609-15.

25 Verheugt $\mathbb{F}$, Brugada P, Dassen WR, Eenige $v$ MJ, Res JC, Simooms ML, Serilys. PW, Vermeet F. Hoogenthuze $v D$, Remme WJ, Zwaan d C, Bär FW. Bleeding complications of intracoronary fi. brinolytic therapy in acute myocardial infarction. Assessment of risk in a randomized trial. Br Heart a $1985 ; 54: 455 i-9$.

26 Vermeer F, Simoons ML, Bär FW, Tijssen JG, Domburg v RT, Seruys PW, Werheugt FW, Res JC, Zwan d $C$, Laarse vd A, Krauss XH, Lubsen J, Hugenholtz $P G$. Which patients benefit mast from early thrombolytic therapy with intracoronary streptokinase? Cicullaton 1986;74:1379-89.

27 Vermeer F, Simoons ML, Feyter d PJ, Bar FW. Suryapranata H, Foretti P. Serruys BW, Buis B, Res JC, Brat S, Lubsen J, Hugenholtz P. Immediate PTCA after successful thrombolysiswith intracoronary streptokinase, three years follow-up. Eur Heart J 1988:9:346-53. 


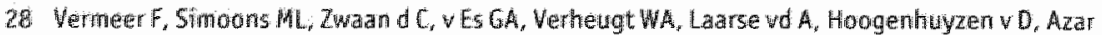
A, Dalen $\mathrm{FJ}$, Lubsen. Hugenholt PG. Cast benefit andysis of early thrombolytic treatment whth intracoronary streptokinesw. Br Heart J 1989;59:527.34.

29 Vemer $F$, Latre vo $A$. Cumulative enzyme retease as measure of infarct size in patients. whith acute myocardial infarction receining thrombolytic therapy. Arch Mall Coets 1993:86:25 .

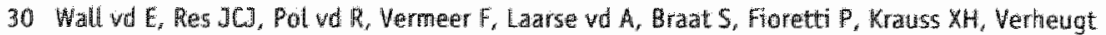
FWA, Simoons BL. Improwement of myocardial perfusian after thrombolysis assessed by thatburm-201 exercise scintignahy. Eur Heart J 1988:9:828-35.

31 Kennedy JW. 50th Anniversary histonical anticle: thrombolytic therapy in acute nyocardial infarction. J. An. Coll. Cardiol, 1999.33:1829m32.

32 Brat SH, Gorgets APM, Bar FW, Wellems HJJ. Value of the ST 1 segment in lead V4R inferior wall acute myocardiat infarction to predict the site of coronary arterial occlusion. Am J Cardiol $1988: 62 ; 140-3$.

33 Bär FW, Volders GA, Hoppener P. Vermeen $F$, Meyer $]$, Wellens HyJ. The development of 5 T-segment elevation arid $Q$ - and $R$-wave changes in the acute and subacute phase of myocar dial infarction. The influence of reperfusion. Am J Cardiol 1995;77:337 43 .

34 Gorgels AP, Vos MA, Letsch I, Verschuuren $\mathbb{E}_{*}$ Bär FW, Janssen JH, Wellens HJJ. Usefulness of the accelerated idiowentricular mythm as a marker for myocardiat necrosis and reperfusion duning thrombolytic therapy in acute myocardial infarction. Am J Cardiol 1988;61:1-7.

35 Gressin V, Gorgels APM, Louward Y, Maison-BLanche P. Reconsidering arrhythmias as markers pf reperfusion. Combined arhythmia and ST-segment analysis diring myocardial infarction. 3 Electrocardiography $1994 ; 26: 262-9$.

36 Klootwijk P. Langer A, Mefi 5 , et al. Non-invasive prediction of reperfusion and coronary artery patency by continuous ST-segment monitoring in the GUSTO-1 trial. Eur Heart 3 $1996 ; 17: 689-8$.

37 Oude Ophuis AJM, Bär FW, Janssen WJ, Vermeer $F_{s}$ Dassen WRM, Weltens HJJ. Anghographic validation of bedside markers of coronary reperfusion in acute myocarbial infarction; can unecessary emergency angioplasties be reduced? A prospective study. I Am Coll Cardiol $1999: 31: 200 \mathrm{~A}$.

38 Doevendans P. Gorgels AP, Zee wd R, Partouns J, Bär FW, Wellens HJ. Electrocardiographic diagnosis of reperfusion during thrombolytic therapy in acute myocardial infarction. Am J Cardio $1995 ; 75: 1206-10$.

39 Oude Ophuis AJ, Bär FW, Vermeer F, Janssen W, Neven K, Doevendans PA, Dassen WR, Wellens HJJ. The prospective use of non-inwasive reperfusion parameters in patients with acute myocardial infarction can limit acute coronary angiography. Revision process Heart.

40 Engelen DJ, Gorgets AP, Cheriex EC, et al. Walue of the electrocardiogram in localizing the occlusion site in the left anterior descending coronary artery in acute anterior myocardial infarction. J Am Coll Cardiol 1999, in press.

41 Chillou 6 , Rodriguez LM Doevendans P. Loutsidis K, Dool wd A. Metzger J, Bar FW, Smeets J, Vellens. HJJ. Factors influencing changes in the signal averaged electrocardiogram within the hrst year after a first myocardial Infarction. Am Heant J 1994:128:263-70.

INAUGURELEREDE 


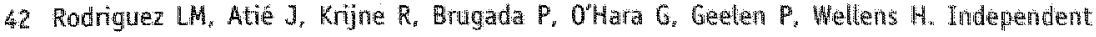
prognostic significance of signal averaged electrocardiogram and ejection fraction after myocandial inferction. Arq Bras Cardiol 1989;53:18.

43 Doewendans P, Loutcidis K, Dool wd A, Metzger J, Bär FW, Smeets J, Wellens HJ J, Effect on the signal averaged electrocardiogram of opening the coronary artery by thrombolytic therapy or percutaneous transtuminal coronary angioplasty during acute myocardial infarction. Am J Cardiol 1993:71:805-9.

4.4 Chillou d C, Rodriguez LM, Doewendams P. Loutsidis K, Dool vi A, Metzger J, Bär FW, Smeets JLRW, Wellens HJJ. Effects on the signal-averaged electrocardiogram of opening the coronary artery by thrombolytic therapy or percutameous transluminal coronary angioplasty during acute myocardial infarction. An J Cardiol 1993;71:805-9.

45 Chillow d C. Doevendans P, Cheriex E. Rodriquez LM, Metzger J, Pieters J, Pieters F, Smeets JLRM, Weillens HJJ. Echocardiographic wall motion abnornalities and the signal averaged electrocardiogram in the acute phase of a first myocardiat infanction. Eur Heart $y$ 1993:14:795-8.

46 Danzig $\vee J M$, Delemarre BJ, Koster RW, Bos $H_{5}$ Visser CA. Pathogenesis of mitral regurgitation in acute myocardial infarction: Importance of changes of left ventricular shape and regional function. Am Heart J 1996;131:865-71.

47 Brat SH, Swart d $H$, Rigo P, Koppejan $L$, Heidendal GAK, Wellens HaJ. Value of technetium MIBI to detect short lasting episodies of severe myocardial ischemia and to estimate the area at nisk during coronary angioplasty. Eur Heart $\mathbf{I} 1991 ; 12: 30-3$.

48 Braat $5 H_{*}$ Swart d $H_{*}$ Janssen $J H$, Birugada P, Rigo P, wellens HJJ. Use of Technetium-99 m Sestamibi to determine the size of the myocartial area perfused by a coronary artery. Am Cardiol 1990,66:85E-90E.

49 Hermens WTh, Veen vd FH, Willems GM, Reneman RS. Enzymatic infarct size and its significance for evaluation of thrombolytic therapy after acute myocardiall infarction. Circulation $1990 ; 81: 1719-20$

50 Veen w FH, Hermans WTh, Willems GM, Reneman RS. Recovery in plasma of cardiac enzymes after regional infairction in the dog. Procedings of the Scientific Conference on Myocardial Cell Wiability 1989:B.

51 Was J, Tyssen JPG, Vermeer F, Verheugt FWA, Krauss XH, Manger Cats W, Simoons ML. Prognostic value of pre-discharge exercise tests in patients with or without thrombolytic therapy. Eur Heart J 1989:10:23.4.

52 Bär FW, Cheriex EC, Gorgels AP, Smeets J, Whellens HJJ, Risk stratification and treatment of acute coronary syndromes and their complications, Neth J Cardial 1991:5:251-5.

53 Bär FW. Clinical implications of thrombolytic treatment in patients with acute myocardial Intarction. In: Every day problems in clinical cardiology. P. Brugada (Ed), Maastricht $1990 ; 1: 6$.

54. Doevendans $P A$, Cheriex $E$, Zee wd $R$, Dooll vd A et al. Risil stratification in the thrombolytic era: results of a prospective study. Cardialogy 1996:3:319-23.

55 Simoons ML, Vos J, Tyssen JPG, Vermeer F, Vertheugt FWA, Krats. XH, Manger Cats V. Which factors determine long term benefit after thrombolytic therapy? Eur Heart $\mathbb{1} 1989 ; 10: 197$.

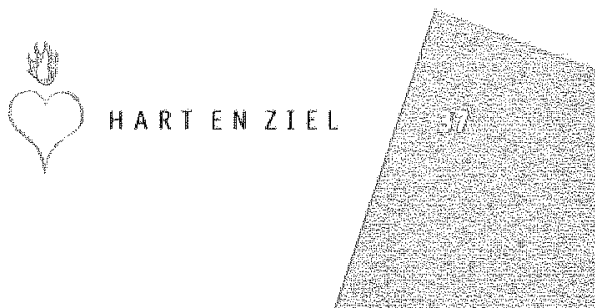


56 Wellens Ha, Conover $\mathrm{B}$. The EC in emergency decision makng. Wo Saunders Company. Shladelpina, 1992 .

57 Bar FW. Thrombolysis for avery myetardial infatction? Weth I Cardiol 1988;1:65-6.

58. Gar FW, Raynaud $P$, Remkin $P$, Vermeer F, Zwand $C$. Wellens HJ. Coronary angiographic findings do not predict dimical cutcome in patients wh unstable angina. J Am Coll Cardiol $1994 ; 24: 1453-9$.

59 Bar FW, Vaheuge FW, Col J, Mateme P, Monassier JP, Geshn PG, Metzger J, Raynaud P. frowcult 3 , Zwala $d C$, Wermeer $F$. Thrombolysig in patients with unstable angina does improve the anglographic but not the clinical outcome. Results of UNASEN, a multicentre, randow mized, placebo controlled, clinical trial. Cinculation 1992;86:131-7.

60 Bar FW, Cheriex EC, Gorge Ls A.PM, Sheets JLRM, Wellens HJ. Risk stratification and treatment of acute coronary syndromes and their complications. Neth J Cardiol 1991; $4: 251-5$.

61 Bar F.W, Zwath $d$ C, Vermeer F. Thrombolyse bij onstabiate angina pectoris. Ned Tijdschr Cardial $1989 ; 8: 602-13$.

62 Zwaan $d C$, Bar FW, Gorgels AG, Wellens HJ. Uristable Angina: Are we able to recognize high-ris patients? Chest $1997,12 * 2,44,50$.

63 Zwaan d C. Bär FW, Janssen JH, Cheriex EC, Dassen WR, Brugada P, Penn OC, Wellens HJ. Angiographic and cinicat characteristics of patients with unstable angina showing an ECG pattern indicating critical narrowing of the proximal $\angle A D$ coronary artery. An Heart I $1989 ; 117,657-65$.

64 2wanar d C, Bär FW, Janssen JH, Swart d H, Vermeer F, Wellens H3J. Effects of thrombolytic therapy in unstable angina: Clinical and angiographic results. I AM Coll Cardiol $1988 ; 12: 301-9$.

65 Zwaan d C. Băr FW, Wellens HJJ. A characteristic electrocardiographic pattern indicating a cuitical stenosis high in the left anterior descending cononary artery in patients admitted because of an impending myocardial infarction. Am Heart J 1982;103:730-5.

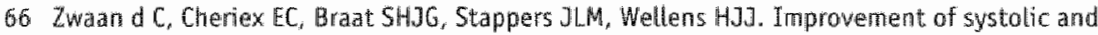
diastotic teft wentricular wall motion by serial echocardiograms in selected patients treated for unstable angina. Am Heart J 1991:121:789-97.

67 Zwan d 6 . Renkin J. Regional wall motion in patients with unstable angina pectoris in a placebo controlled thrombolysis study. I Am Coll Cardiat 1991;17:319.

68 Zwaan d C. Herkenning van een subgroep van pattënten met onstabiele angina pectoris en een werhoogd risico op een uitgebreid myocardinfarct en op overijden. Ned Tijidschr Cardiol $1989 ; 8: 284-7$.

69 Zwaan d C. Recognition of high risk patients with acute myocardial ischemia. Thesis; Mas. tricht, 1989.

70 Zwatan d C. Thrombalytic therapy in unstable angina. Cardiovascular Reviews and Reports $1989 \div 9: 15-21$.

71 wath $\mathrm{d}$. Thrombolytic treatment in unstabla angina. Lessons from overvews of the trials. Tromb Haemostasis 1991:65:751. 


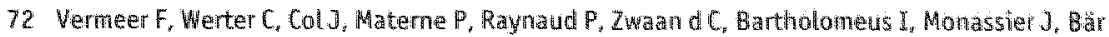
FW. Improved coronary anatomy after thrombolysis in patients wh undable angina. The UNASEM study. Results of quantitative coronary angiography. Ciculation 1991:84:52.

73 Diwer DJ, Ber JD, Ferreira PE, al. Climical and angiographic charactentsation of patients with unstable angina without critical coronany and arterial marrowing ffrom the TINI IMA trial. Am J Cardiol 1995;74:531-7.

7. TIMI Group. Effects of tissue plasminogen activator and a comparison of early invastwe and conservative strategies in unstable angina and non $D$ wave myocardial infarction. Results of the TIHIIIIB trial. Circulation 1994;89:1545-56.

75 Diefenbach $\mathrm{CH}$; on behalf of the PRIMI-study group. one year follow-up in a randomised double blund triat of saruplase versus streptokinase in acute myocandial infatiotion. Long term results of the PRIMI-triall. Coron A.ren D 1992;3:925-31.

76 Meyer 3, Bär FW, Barth H, Charbonner B. El Deeb MF, Erbel Re Flohe L, Giulker H, Heikkila J, Massiberg I, Matthey D, Monassier JP, Probst P, Schmitz-Hubner U, Seabra-Gomes R, Stmupp G, Uebis $R_{r}$ Vermeer $F$, Werf $v d F$, Westerhof $P$, Windeler $I$. Randomised double blind trial of re combinant pro-Urokinase against streptokinase in acute myocardial Infarction. Lancet 1989:863-8.

77 Osterman H, Schmitz.Huebner U, Windeler J. Bär FW, Meyer J, Loo vd J. Rate of fibrimogen breakdown is related to coronary patency and bleeding complications in patients with thrombolysis in acute myocardial infarction. Results of the PRIMI trial. Eur Heart $J$ $1992 ; 13: 1225-32$.

78 Spiecker M. Windeler J. Vermeer F, Michels $H r$, Seabra-Gomes R, Dahl w J, Breithardt $G$. Verheugt WA, Westerhof PW, Bär FW, Nixdorf U, Barth H, Hopkins GR, Fisenne vMMM, Meyer J. Thrombolysis with saruphase versus streptoknase in acute myocardial infarction: five-years results of the PRIMI triat. Submitted for publication.

79 Vermeer F, Bösl 1, Meyer J, Bär FW, Charbonnier B, Windeler J, Barth B. Saruplase is a saffe and effective thrombolytic agent; observations in 1698 patients. J Thromb Thrombolysis $1999 ; 8: 143-50$.

80 Vermeer F, Meyer J, Bär F.W, Erbel R, Mathey D, Uebsis R, El Deeb M, Monassier J,P. Westerhof P. Boss H, Gülker $H_{*}$ Charbonnier B, Seabra-Gomes R, Probstit P, Heikkila J, Stupp G, Schmitz-Huebner U, Trampisch H.J, Massberg 1 , Barth H. Early reperfusion after treatment with pro-urokinase when compared to intravenous streptakinase. I Am Coll Card $1989 ; 10: 152$.

81 Bär FW, Meyer $]$, Vermeer F, Michels HR, Charbonier B, Haerten K, Spiecker M, Macaya $E_{*}$

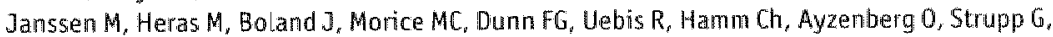
Withagen Ad, Klein P, Windeler J, Hopkins G, Barth H, Fisenne w. Earty patency and reocclusion: Comparison of saruplase and alteplase in acute myocardial Infarction. From the SESAM study. Am J Cardiol 1997;79:727-32.

82 Vermeer Findeler J, Riedel $A, B a r h$ H. Bar FW. Final report of the practical applicability of saruplase study (PASS): the efficacy and safety of saruplase tested in 1698 patients. 2 Kardiol $1993 \div 82 / 3: 4: 4 * 544$ 


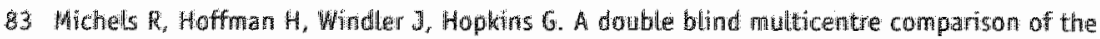
efficacy and saffey of saruplase in the treatment of acute myocardial infarction. Report of the SUTAllt study group. J Trombogs and Thrombotysis $1995 ; 2: 117-24$.

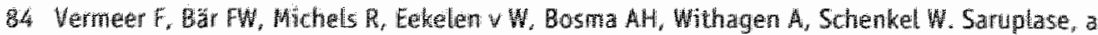
nesw fibrin specife thromblytic agent; efficacy and safety data of 1400 patients. Neth Cardiol $1991: 4: 255$.

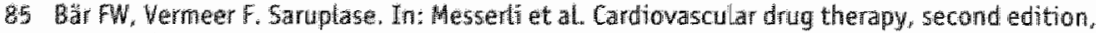
1997. WB Sanders Company, Philadelpha; $1587-93$.

86 Vemeer $F$. The adverse ewent and tolerability profite of saruplase. Rev. Contemp. Pharmacother. $1998 ; 9: 385-93$.

37 Vermeer F, Malanen v $\mathrm{R}$, Bar FW. Thrombolyse bij patienten ouder dan 75 jaar. Hartbulletin 1998; 3: 89:93.

88 Bär F, Vermeer F, Michels R, Boland $\mathrm{J}$, Meyer J, Hopkims G, Barth H, Grunzler W. Saruplase in myocardial Infarction. I Thrombosis en Thrombolysis 1995:2:195-204.

89 Darius $H$. Meyer 3 , on behalf of the PRIMI trial study group. Pecombinant pro-urokinase wersus streptokinase in acute myocardial infarchion. Cardiovascular Reviews and Reports 1991;56-9.

90 Vermeer $F$. Mode of action and pharmacology of saruplase. Int J clin Pract 1998; 599: 5-8.

91. Bar FW, Meyer J, Michels $R$, Uebis $R$, Lange $S$, Barth $H$, Groves $R$, Vermeer F: Taprostene might improwe the effect of thrombolytic treatment in acute myocardial infarction. Results of the START study. Eur Heart $19993,14: 1118-26$.

92 ISIS-2 (Second International Study of Infarct Survival). Collaborative Group. Randomized thial of intravenous streptokmase, oral aspirin, both, or neither among 17,187 cases of suspected acute myocardial infarction: ISIS-2. Lancet 1988;2:349-60.

93 Antman EM, Giugliano RP, Gibson CH, al. Abciximab fascilitates the rate and extent of thrombolysis. Results of the TIMI 14 trial. Circulation $1990 ; 99 \div 2720-32$.

94. Merkhof vd LF, Zijlstra F, OLon $H$, Grip L, Veen $G$, Bar FW, Brand wd MJ, Simoons ML, Verheugt FW. Abciximal in the treatment of acute myocardial infarction eligible for primary FTCA. Results of the Glycoprotein Receptor Antagonist Patency Evaluation (GRAPE) pillor study. J Ami Coll Cardiol 1999;3:1528-32.

95 The PARAGON investigators. International, randomized controlled trial of lamifiban (a platelet glycoprotein $\mathbb{I b} / \mathrm{Ml}$ a imhibitor, heparin, or both in unstable angina. Circulation $1998 ; 97: 2386-95$.

96 The PRISM study investigators. A companison of aspirin plus tirofiban with aspirin plus heparin for unstable angina. N Engl J Med 1998;338:1498-505.

97 The PRISM-PLUS study inwestigators. Inhibition of the platelet glycoprotein IIb/IIIa receptor with tirofiban in unstable angina and non-Q wave myocardial infarction. N Engl J Med 1998;338:1488-97.

98 The PuRSUL trial investigators. Inhibition of platelet glycoprotein IIb/II anth eptifibatide fin patients with acute coronary syndromes. N Engl J Med 1998;229:436-4a.

99 The CAPTURE Investigators, Randomised placebo controlled triat of abciximab before and during coronary intervention in refactory unstable angina: the CAPTURE study. Lancet $1997,349: 1429-35$. 
100 The EFIC investigators. Use of a monoclonal antibody diretted against the platelet wytopor

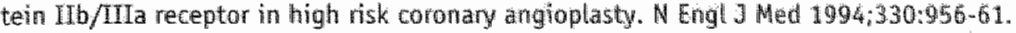

101 The IMPACT-II Inwestigators. Randomised placebo-controlled trial of effect of eptrifatide on

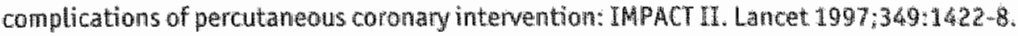

102 Ohman EM, Kleman NS, Gacioch $G$, et al. Combined accelerated tissue-plasminogen actvator and platelet glycoprotein IIb/TIa receptor blockace with vintegrilin in acute myocardial infarction. Results of a randomized, placebo-combrollew, dose ranging trial. circulation $1997: 95: 8.46-54$

103 Epilog Investigators. Effect of the platelet glycoprotein II with lower heparin dosages on ischemic complications of percutaneous cononary revascularization. N Engl J Med 19:97:336:1689-96.

10. Gibbons RJ, Holmes DR, Reeder 65, Bailey KR, Hopfenspirger MR, Gersh BJ, for the Wayo Cord nary Unit and Catheterization Laboratory Groups: Immediate angioplasty compared with the administration of a thrombolytic agent followed by conservative treatment for myocardial infarction. N Engl J Med 1993; 328:685-91.

105 Grines CL, Browne KF, Marco J, et al, for the Prinary Angioplasty in Myocardial Infarction Study Group. A comparison of immediate angioplasty with thrombolytic therapy for acute myocardial infarction. Engl J Med 1993:328:673-9.

106 Zijlstra F, de Boer MJ, Hoorntie JC, Reiffers 5 . Reiber JH, Suryapranata H. Comparison of immediate coronary angioplasty with intravenous streptokinase in acute myocardial infarc tion. N Engl J Med 1993; $328: 680-4$.

107 The Global Use of Strategies to open occluded coronary arteries in acute coronary syndromes. (Gusto ITb)angioplasty substudy inwestigators. A clinical trial companing primary coronary angioplasty with tissue plasminogen activator for acute myocardial infarction. N Eng J Med $1997 \div 336: 1621-8$

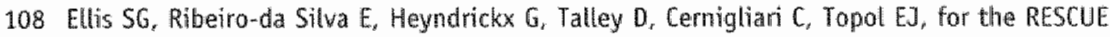
Investigators. Randomized comparison of rescue angioplasty with conservative management: of patients with early fallure of thrombolysis for AMI. Circulation 1994; $90: 2280<4$.

109 Bär FW, Oude Ophuis AJM, Frederiks J, Swart d H, Ommen v V. Zwaan d C, Vermeer F, Gorgels AP, Wellens HJJ. Rescue PTCA following failed thrombolysis and Primary PTCA: A retrospective study of angiographic and clinical outcome. J Thrombosis Thrombolysis $1997 ; 4: 281-8$.

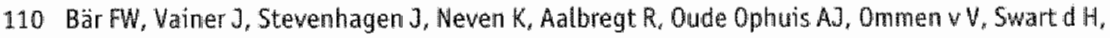
Muinck $d E_{s}$ Dassen W, Wellens. HJJ. Ten years experience with early angioplasty in 759 patients with acute myocardial infarction. 3 Am Coll Cardiol in progress.

111 Suryapranata $H$, Serruys PW, Vermeer F, Feyter d PJ, Brand vd M, Simoons ML, Bar FW, Res JC, Laarse vd A, Domburg $\vee R$, Beatt $K$, Lubsen J, Hugenholtz PG. Value of immediate coronary angioplasty following intracoronary thrombolysis in acute myocardial Infarction. Catheterization Cardiovascular Diagnosis 1987;13:223-32.

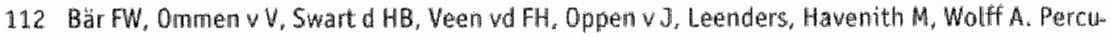
taneous implantation of new intra coronary stent in pigs. Am Heart J 1991;6:1532-41.

113 Opperv v , Ommen v V, Bär FW, Swart d JB, Veen wd FH, Wellens HJd. Complications after ntrat coronary stent implantation: three cases. Cardiology 1992;80:126-131.

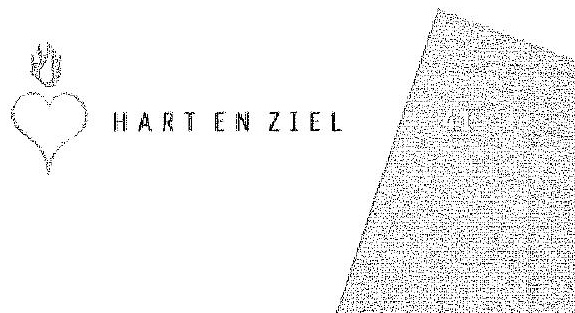




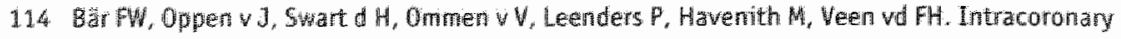
stents. In: Complicathon after PTCA. Fleck and Frantz (eds). Steinkopf Verlag Darmstadt 1991: $100-13$.

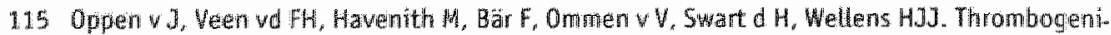
city of a paraltew wre, selfexpanding stent in an aonta loop in rats. Int a Angiol $1992 ; 1: 63=70$.

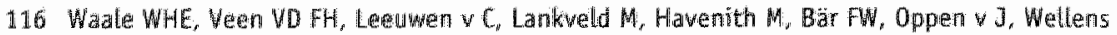
HJJ. Modulation of healthy pig coronary arteries by self-expanding stents. I Interv Cardhol $1996,9: 45 \times 52$.

117 Muinck \& ED, Swart d JB, Ommen \& GVA, Bär FW. Intracoronaire stents. Hartbulletin $1996: 27: 67-71$.

118. Benzina A, Kruft MAB, Bä FW, Veen wd FH, Bastiansen CW, Heijnen V, Reutelingsperger C, Koole $1 H$. Studies on a new radiopaque polymeric biomaterial. Biomaterials 1994:15:1122-8.

119: Kruft MAB, Benzina A, Bär FW, Veen va FH, bastiaansen CHA, Blezer $\mathrm{R}$, Lindhout $T$ Koole $\mathrm{LH}$. Studies on two new radiopaque polymeric biomaterials. J Biomed Mater Res 1994,28 : $1259 \times 66$.

120 The TIMI Research Group. Immediate vs. delayed catheterization and angiaplasty following thrombolytic therapy for acute myocardial infarction: TIMI II-A results. JAMA 1988; 260:2849-58.

121 Simoons ML, Ainold AER, Betriu A, et al, for the European Cooperative Study Group for recombinant tisue-type plasminogen actiwator (rTPA). Thrombolysis with tissue plasminogen activator in acute myocardial infarction: no additional benefit from inmediate percutaneous coronary angioplasty. Lancet 1988;197-203.

122 Ommen v GWA, Veen vo FH, Geskes G, Daemen M, Habets ${ }_{3}$, Dassen WRM, Wellens HJJ. Companusom of arterial wall reaction after passage of the hydrolyser device wersus a thrombectomy balloon in an animal modet. J Vasc Interventional Radiology 1996\%7:451-4.

123 Ommen $v$ GVA. The Hydrolyser, a hydrodynamic thrombectomy catheter to remove thrombi form the cardiovascular system. Thesis; Mastricht: 1998.

124 Ommen w GVA, Veen wd FH, Daemen MJ, Habets J, Wellens HJJ. In wivo evaluation of the hydrolyser hydrodynamic thrombectomy catheter. I Vasic Interventional Radiology $1994 ; 5: 823-6$

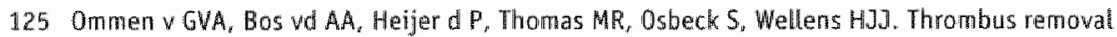
from bypass grafts and native arteries using the f6 Hydrolysers: Clinical results. I Invas Cardiol 1996;8:90.

126 Oude Ophuis AJM, Bär FW, Vermeer $F$, Krijne $R$, Jansen W, Swart $d H$, Ommen $v$ V, Zwaan d $C$. Engelen $D$, Dassen WR, Wellens 4 J J. Early referral for intention rescie PTCA after initiation of thrombolytic therapy in patients admitted to a community hospitall with a large acute myocardial intarction. Am Heart 3 1999:137:846-53.

127 Otude Ophuis AM, Bär FW. Rescue PTCA in Nederland: wat, waar, wie, en wanneer? Cardiologie $1997: 4: 451-5$.

128 Vermeer F, Oude Ophuis AJ, Berg vd EJ, Brwninkhuis LG, Werter Cd, Boehmer AG, Lousberg AH. Dassen WR, Bar FW. Prospectiwe randomised companson between thrombolysis, restue 
PTCA and primary PTCA in patients with extensive myocardial infarction admithed to hospital without PTCA facilities. The LIMI study. Heart 1999:81: in print.

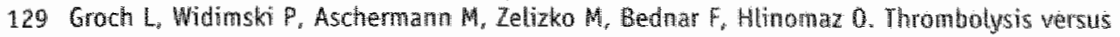
PTCA versus both in patients with acute myocardial intarction Pracie triaty coronaryarapty findings and PTCA results. Eur Heart J 1999;20:32.

130 The European Myocardial Infarction Project Group. Pre-hospital thrombolytic therapy in patients with suspected acute myocardial infarction. N Engl J Med 1993;329:383-9.

131 Great group. Feasibility, safety, and efficacy of domiciliary thrombolysis by genteral practition ners: Grampian Region Early Anistreplase Trial. Bh.] 1992;305:548-53.

132 Bär FW, Spamjers M. Hopkins G. Bolus Administation of thrombolytic therapy. Rev Contemp Phamacother 1998;9:379-8,4.

133 Relik-wan Wely T, Visser RF, Pol wd J, et al. Angiognaphically assessed coronary artenal patency and reocclusion in patients with acute myocardial infarction treated with anistre plase: results of the Anistreplase Reocclusion Multicentre 5tudy (ARMS). Am II Cardiol $1991 ; 68 ; 296-300$.

134 Bonner HJRM, Visser RF, Klomps HC, et al. Comparison of intravenous anisoylated plasnino ogen streptokinase activator complex and intracoronary streptokinase in acute myocardial infarction. Am J Cardiol 198:8;62:25-30.

135 Bär FW, Meyer J, Boland J, Betriu A, Artmeyer B, Charbonner B, Michets HR, Tebbe U, Sprecken

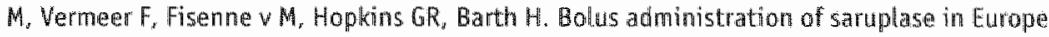
(BASE), a pilot study in patients with acute myocardial infarction. J Thrombosis and Thronibolysis $1998 ; 6: 147-53$.

136 Bär FW, et al. The bolus infusion in rescuepase (saruplase) development (BIRD) study in 2410 patients with acute myocardial infarction. Abstract.

137 Heijer d P, Vermeer F, Ambrosioni $E$, on behalf of the InTME Investigatars. Evaluation of a weight-adjusted single-bolus plasminogen activator in patients with myocardial infarction. Circulation 1998; 98:2117-25.

138 Widdershoven JWMG, Gorgels APM, Wermeer F, et aL. Changing characteristics and in-hospital outcome in patients admitted with acute myocardial infarction. Eur Heart i] $1997 ; 18: 1073-80$.

139 Wellens $\mathrm{HJJ}$. Sudden death late after a myocardial infarction: substrate and risk stratification. In sudden cardiac death: prevalence, mechanisms, and approaches to diagnosis and management. Akktar M, Myerburg RJ, Ruskin JM (eds) William and Wilkinis, Philadelplya; $1994: 147-54$.

140 Widdershoven JWMG, Gorgels A.PM, Vermeer F, Dassen WRM, Wellens H.J. Weranderingen in patiërtenkenmerken en prognose wan het acute myocardinfarct in de regio Mastricht. Hartbulletin 1998;29:189-92.

141. Widdershoven J. Acute coronary syndromes in the Mastricht ared. Acute myocardial infarc tion, unstable angina. Thesis; Mastricht: 1997

142 Swagemakers JJ, Verstraten GM, Gorge Is AP, Dullens IM, Vermeer F. Wellens HJJ. Did prognasis after acute myocardial infarction change during the last 30 years? A mata analysis. Wortd Congress of Cardiology 1990. 


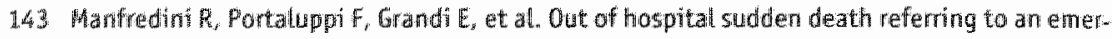
gency departinent. J clin Epidimiol 1996;49:865-8.

14.4 Wellens HJJ. Key referritues on sudden death. Circulation 1994:90:2547-53.

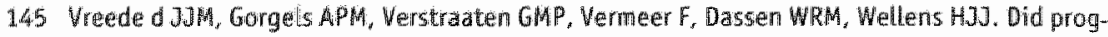
nosis after acutc myocardial infarction change during the past 30 years? A meta-analysis. 3 Am Coll Cardiol 1991:18:698-706.

146 Wellens HJ. Wreede d J, Gorgels AP. Sudden cardiac death. How to reduce the number of victions? Eur Heart 3 1995;16:7-9.

147 Vreede-Swagemakers JJM, Gorgels APM, Dubots-Arbouw Wa Dalstra I, Daemen MAMP. Ree JW, Stifins RE, Wellens HJ. Circumstances and causes of wut-of hospital cardiac anrest in sudden death surwors. Heart 1998; 79:556-61.

148 Vreede oJ JM. Acute comonary syndromes in the Mastricht area. Sudden cardiac arrest. Thesis; Mastricht: 1997.

149 Rodriguez LM, Oyarzun R, Smeets J. Brachmann J, Schmitt C, Brugada P, Geelen P, Lipcsei G, Albert A. Wellens HJJ. Identification of patients at high risk for recurrence of sustained wentricular tachycardia after healing of acute myocardial infarction. Am J Cardiol 1992;69:462-4.

150 Wellens HJJ. Risk stratification of patients with ventricular tachycardia or ventricular fibrillation after myocardial infarction. The walue of the clincal history. Eur Heart J 1989:10:747-52.

15.1 Wellens HJJ. Risk stratification. In: Sudden cardiac death: Prevalence, mechanisms, and approaches to diagnosis and management. Akhtar M, Myerburg RJ, Ruskin JN (eds). Whiliam \& Wilkins, Philadelphia, 1994:147-54.

152. Trappe HJ, Brugada P, Talajic M, Lezaun R. Wellens HJJ. Kammertachykardien und Kammerflimmeri nach Myokardinfarkt: Determinanten für Prognose und Verlauf. Zeitschrift fur Kand: ologie 1988,77:687-95.

153 Vos MA, Gorgels APM, Leunissen JDM, Hawenith MG, Kriek E, Smeets JLRM, Wellens HJJ. Programmed electrical stimulation and drugs indentify two subgroups of ventricular tachycardias occurring 16-24 hours after occlusion of the left anterior descending artery. Circulation $1992 ; 85: 747 \times 55$.

15 Rosengwist M, Beyer Th, Block M, Dulk d K, Minten J, Lindernans $F$, on behalf of the European 7219 Jewel ICo Investigators. Adverse events with transveneous implantable cardioverter-defibrillators. Circulation 1998; 98: 663-70.

155 Soons PHGM. Bär FW. Hartrevalidatie. Medisch Contact 1996:14:464.

156 Soons PHGM. Hartrevaldatie in Nederland: geregistreend en geëvalueerd. Thesis; Maastricht: 1995 .

157 Bär FW, Vonken HJ. Wat is het nut van hartrewalidatie? Ned Tijdschr Geneesk 1990;134: $107-12$

158 Bär FW. Hartiewalidatie: wat te verwachten? Hartbulletin 1992;23:103.

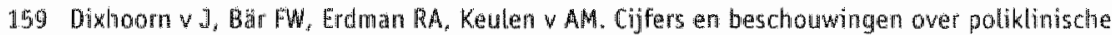
harthevalidatie: een inventarisatie. Hartbulletin 1988;19:11-20.

160 Erdman J, Bar FW. Psychosociale factoren en coronaire hartziekten: werslag van een workshop. Hartbulletin 1988;19:67-9. 
161 Soons P. Bär FW. Revatidiatie van hartpatiënten thderis opname en na ontslag ust het ziakenhuis:" cijfers en trends. Ned Tijdschr Geneesh 1990:134:1034.

162 Appets A, Bar FW, Lasker J, Flarmin $U_{3}$ Kop W. The effact of a psychological intentention progiram on the risk of a new coronary event after angioplasty: a feasibility study: I Psychosomatic Research 1997; 43:209-17.

163 Mendes de Leor CF, Kop WJ, Swant HB, BäF F Appels AP. Psychological characteristics and recurrent events: after PTCA. Am J Cardiol 1996;77:252 -5.

164 Bär FW, Höppener P, Diederiks J, Vonken H, Bekkers J. Hoofd vh W, Appels A, Wellens HJJ. Cardiac rehabilitation contributes to the restoration of leisure and social activities atter myocardial infarction. J Cardiopulmonary Rehabil 1992;12:117-25.

165 Bär FW, Wonken HJ, Cluitmans J. Cardiac rehabilitation to the rehabilitation center Moensbroeck*. Neth J Cardiol 1988;1:1.

166 Cluitmans JJM, Vonken $H_{*}$ Băr FW. Deel 5: Hartrewalidatie en specialistische rewalidatie. Cardologie 1996;3:296-8.

167 Chitmans $3 J M$, Vonken H. Bär AW. Deel 6: Hartrevalidatie in revalidatiecentrum "Hoensbroeck" Cardiologie $1996,367 \% 9$.

168 Vonken HJM. Bär FW, Cluitmans JJM. Klinsche hatrevalidatie: Vijftien jaar erwang in "Hoensbroeck". Hartbulletin 1996;27:97-101.

169 Soons PHGM, Bär FW. De rol van de huisarts bij revalidatie van pattënten na een hattinfarct. Hartbulletin 1996;27:93-6.

170 Falger PRJ. Gedragswerancieringen en secundaire preventhe van hartlijden: een overzicht. Gedrag \& Gezondheid 1993;21:286-97.

171 Sebregts EH, Falger PR, Bär FW. Gedragswerandering beinwloedt risicofactoren coronariak lijden. Hartbulletin 1997:28:160:70.

172 Hofstra L, Muinck dE, Doevendans PA. Molecular Cardiology. Part 7: Apoptosis in the cardiovascular system. Cardiologie 1998:589-93.

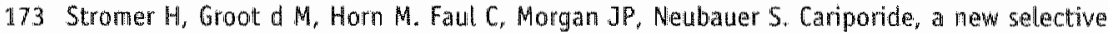
$\mathrm{Na}+/ \mathrm{H}+$ exchange inhibitor, improwes postischemic recovery by attentuating Cact-overload and prolonging acidosis upon reperfusion. Eur Heant J 1999;20:161.

174 Doeveridans PA, Bronsaert R, Meijer H, Bär FW. Moleculaire cardiologie: wetenschappelijk onderzoek en patièntenzorg.

175 Doevendans PA. The Human Gemome Program is ready for us, but are we ready for the Genome Program? Cardínologie 1998;10:595-9.

176. Doevendans PA. Evidence-based medicine: cardioprotective strategies, to improwe outcome. Cardiologie 1998;5:6-7.

177 Asahara T, Murohara T, Sulliwan A, Silwer M, Zee vd MC, Li T, Witzenbichler B, Schatteman G. Isner JM. Isolation of putative progenitor endothelial cells for angiogenesis. Science $1997,275: 96: 46-67$.

178 Baumgatmer I, Isner JM. Stimulation of periferal angiogenesis by vascular fondothelial growth factor (WEGH). VASA $1998 ; 27(4): 201 \%$. 


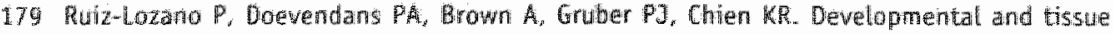
restricted expression of a mun spliceosone related protein mSAP 49 during cardiogenesis. Dew Dynam 1947;208:482-90.

180 Doevendans PA. Applying the human gemome project to cardiovascular research. Lancet $1998 ; 351: 5$.

181. Doevendans PA, Ruiz-Lozano , Eilsen y Hunting down nucleic acid binding factors in the cardiovascular system: Cardiovasc Res $1998 ; 38: 301-5$.

182 Doevendans P, Reneman W; Bitsenv Workshop on cardiovascular specific gene expression. Eut J Physiol 1998:46:36:1015-20.

18 Geelen JLMC, Doevendaris PA, Jongbloed RDE, Wellens HJJ. Geraedts JPM. Molecular genetics of inherited long ar syndromes. Eur Heart J 1998;19:14427-33.

184 Bekkere SCAM, Doewendans PA, Zee wd MC. Molecular Cardiology. Part 8" Nitric oxide. Cardia logie 1998:5:658/62.

185 Doevendans PA. Cardomyocyte specific gene expression of the regulatory myosin light chains. Cardiologie $1998 ; 5 \times 281-2$.

186 Doevendans $P A$. Eys $v$ GJG. Meij $d$ J. Aderoviral-mediated gene transfer of the vascular wall. Cardiologie 1998; $5: 653$.

187 Comelussen RNM, Snoecks LHEH, Doevendans. PA. Molecular Cardiology. Part 4: The role of inductble stress proteins in the preservation of myocardial function foltowing ischaemia. Cardiologie 1998;5:263-71.

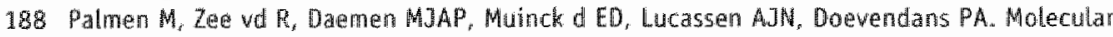
Cardiology. Part 6: Cardiac angiogenesis and growth factors. Cardiologie 1998:5;406-13.

189 Winded LJ, Wilde AAM, Doevendans PA. Molecular cardiology. Part 5: Animal models in molecular candiovascular reseanch. Cardiologie 1998;5:327-35. 

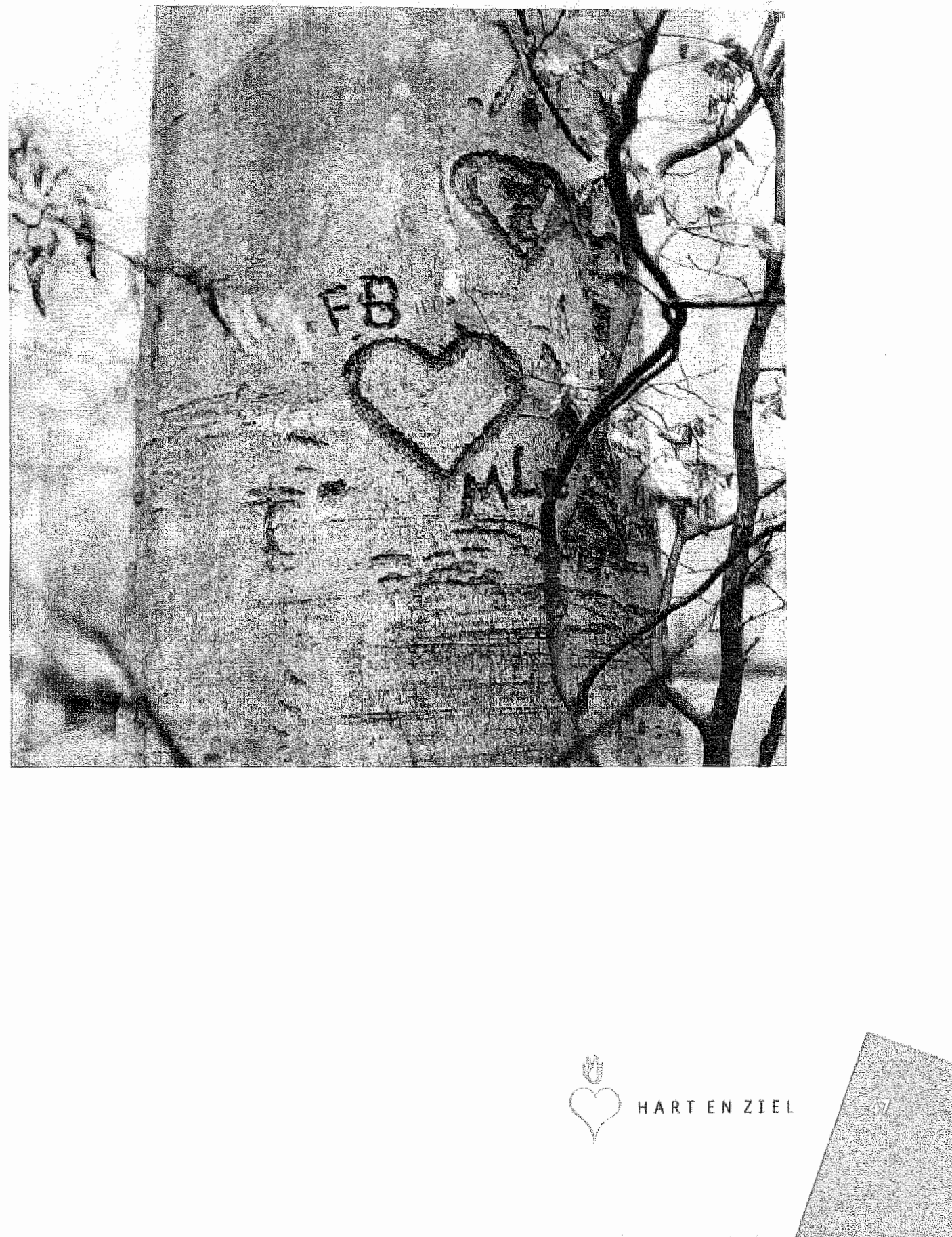
(9) FWH Bar, Maastricht 1999

ISBN $905278258 x$

Unversitäre Pers Mastrictit:

Procluctie en layout: Datawyse bv

I. NAUGURELEREDE 